\title{
Adaptation to Photooxidative Stress: Common and Special Strategies of the Alphaproteobacteria Rhodobacter sphaeroides and Rhodobacter capsulatus
}

\author{
Mathieu K. Licht ${ }^{1}$, Aaron M. Nuss ${ }^{2}$, Marcel Volk ${ }^{1,3}$, Anne Konzer ${ }^{4}$, Michael Beckstette ${ }^{5}$, \\ Bork A. Berghoff $1, *$ (i) and Gabriele Klug ${ }^{1, *}$ \\ 1 Institute of Microbiology and Molecular Biology, University of Giessen, 35392 Giessen, Germany; \\ Mathieu.Licht@mikro.bio.uni-giessen.de (M.K.L.); Marcel.Volk@ukmuenster.de (M.V.) \\ 2 Department of Molecular Infection Biology, Helmholtz Centre for Infection Research, 38124 Braunschweig, \\ Germany; aaron.nuss@microsynth.seqlab.de \\ 3 Institute for Infectiology, Center for Molecular Biology of Inflammation, University of Münster, \\ 48149 Münster, Germany \\ 4 Biomolecular Mass Spectrometry, Max Planck Institute for Heart and Lung Research, 61231 Bad Nauheim, \\ Germany; anne.konzer@gmail.com \\ 5 Department of Computational Biology for Individualized Medicine, Centre for Individualized Infection \\ Medicine, 30625 Hannover, Germany; Michael.Beckstette@helmholtz-hzi.de \\ * Correspondence: Bork.A.Berghoff@mikro.bio.uni-giessen.de (B.A.B.); \\ Gabriele.Klug@mikro.bio.uni-giessen.de (G.K.); Tel.: +49-641-99-35558 (B.A.B.); +49-641-99-35542 (G.K.)
}

Received: 28 January 2020; Accepted: 13 February 2020; Published: 19 February 2020

\begin{abstract}
Photosynthetic bacteria have to deal with the risk of photooxidative stress that occurs in presence of light and oxygen due to the photosensitizing activity of (bacterio-) chlorophylls. Facultative phototrophs of the genus Rhodobacter adapt the formation of photosynthetic complexes to oxygen and light conditions, but cannot completely avoid this stress if environmental conditions suddenly change. $R$. capsulatus has a stronger pigmentation and faster switches to phototrophic growth than $R$. sphaeroides. However, its photooxidative stress response has not been investigated. Here, we compare both species by transcriptomics and proteomics, revealing that proteins involved in oxidation-reduction processes, DNA, and protein damage repair play pivotal roles. These functions are likely universal to many phototrophs. Furthermore, the alternative sigma factors RpoE and $\mathrm{RpoH}_{\mathrm{II}}$ are induced in both species, even though the genetic localization of the rpoE gene, the RpoE protein itself, and probably its regulon, are different. Despite sharing the same habitats, our findings also suggest individual strategies. The crtIB-tspO operon, encoding proteins for biosynthesis of carotenoid precursors and a regulator of photosynthesis, and $c b i X$, encoding a putative ferrochelatase, are induced in R. capsulatus. This specific response might support adaptation by maintaining high carotenoid-to-bacteriochlorophyll ratios and preventing the accumulation of porphyrin-derived photosensitizers.
\end{abstract}

Keywords: Rhodobacter capsulatus; Rhodobacter sphaeroides; photooxidative stress; transcriptomics; proteomics; stress defense

\section{Introduction}

Microbes in aquatic habitats need to adapt to frequent changes in environmental parameters like temperature, $\mathrm{O}_{2}$-saturation, or light conditions. While phototrophic bacteria can take advantage of pigment-protein complexes to use light energy for ATP production, they face the special challenge of photooxidative stress: (bacterio-) chlorophylls can act as photosensitizers and transfer energy to 
the ground state triplet oxygen $\left({ }^{3} \mathrm{O}_{2}\right)$, causing a spin conversion in the $\pi^{*} 2 p$ orbital that generates highly reactive singlet oxygen $\left({ }^{1} \mathrm{O}_{2}\right)$. While other photosensitizers like humic acids also contribute to photooxidative stress, (bacterio-) chlorophyll $a$ is regarded as the main cause of ${ }^{1} \mathrm{O}_{2}$-generation in photosynthetic bacteria. Independently of light, processes like lipid peroxide decomposition or hypochloric acid reacting with hydrogen peroxide can generate ${ }^{1} \mathrm{O}_{2}[1]$.

Facultative anoxygenic phototrophic bacteria of the genus Rhodobacter adjust their lifestyle to the light and oxygen conditions. Due to a high metabolic versatility, they do not rely on photosynthesis for ATP production, but can also perform aerobic or anaerobic respiration or fermentation. They do not form photosynthetic complexes at high oxygen concentrations, and at intermediate oxygen concentration, light inhibits the accumulation of pigment-protein complexes [2,3], which reduces the risk of photooxidative stress. Several protein regulators, including redox-responsive factors, photoreceptors, and even proteins with dual-sensing function like AppA [2], but also RNA regulators [4,5], contribute to the regulated formation of photosynthetic complexes.

Nevertheless, situations that cause photooxidative stress cannot be completely avoided, and consequently, mechanisms to defend this stress are important for survival. As seen across all kingdoms, ${ }^{1} \mathrm{O}_{2}$ damages a wide variety of biomolecules, including nucleic acids, amino acids, fatty acid lipids or thiols, and glutathione $[1,6,7]$. Singlet oxygen can directly oxidize its targets or generate other reactive oxygen species (ROS) like endo- or hydroperoxides via $(4+2)$ cycloaddition or the ene reaction [8]. Without a proper cellular response, ${ }^{1} \mathrm{O}_{2}$-stress can be cytotoxic $[9,10]$. In the case of DNA, the mutagenic potential of ${ }^{1} \mathrm{O}_{2}$ in Escherichia coli can be assigned to the oxidation of guanine sites to 8-oxo-7,8-dihydro-2'-deoxyguanosine (8-OHdG), which is susceptible to single strand breaks $[9,11]$. Regardless of the occurrence of $8-\mathrm{OHdG},{ }^{1} \mathrm{O}_{2}$ can also affect RNA, specifically viral RNA, by mediating RNA-protein-crosslinking, as shown for photoinactivation of HIV-1 [12]. As ${ }^{1} \mathrm{O}_{2}$ can form peroxides, it also targets unsaturated fatty acids, causing lipid peroxidation which impairs membranes in their potential, integrity, or transport activities $[13,14]$. However, due to their high abundance in the cell, proteins are the primary targets of ${ }^{1} \mathrm{O}_{2}$ [15]. Protein damage by ${ }^{1} \mathrm{O}_{2}$ may often be traced back to the oxidization of amino acids containing sulfur or aromatic compounds $[7,16]$, but other ROS generated by ${ }^{1} \mathrm{O}_{2}$ might target the proteome as well. Unfolded or aggregated proteins and the loss of enzyme activities are likely consequences of ${ }^{1} \mathrm{O}_{2}$ [17].

For more than a decade, $R$. sphaeroides have served as the bacterial model organism to elucidate the photooxidative stress response. Increased expression of certain genes in response to ${ }^{1} \mathrm{O}_{2}$ was demonstrated, and an important role of the alternative sigma factors $\mathrm{RpoE}, \mathrm{RpoH}_{\mathrm{I}}$, and $\mathrm{RpoH}_{\mathrm{II}}$ in this response was revealed [10,18-21]. An early step in ${ }^{1} \mathrm{O}_{2}$-dependent gene activation is proteolytic degradation of the antisigma factor ChrR [22,23]. The released RpoE sigma factor directly activates a small number of genes like the DNA photolyase gene $p h r A$ or $c f a S$ (cyclopropane fatty acyl-phospholipid synthase) [24,25], but also the $r p o H_{I I}$ gene. $\mathrm{RpoH}_{\mathrm{II}}$, together with $\mathrm{RpoH}_{\mathrm{I}}$, activates a high number of genes upon photooxidative stress, but also in response to other stresses $[20,21]$. Genes that are activated upon photooxidative stress have functions, e.g., in the detoxification of toxic molecules like peroxides or methylglyoxal, in protein quality control and turnover, in ${ }^{1} \mathrm{O}_{2}$ quenching, DNA repair, and transport [1,26]. Although carotenoids provide protection against ${ }^{1} \mathrm{O}_{2}$ in R. sphaeroides, genes for carotenoid synthesis are not activated by ${ }^{1} \mathrm{O}_{2}$ in this bacterium $[27,28]$.

Regarding the photoprotective function of carotenoids, both $R$. capsulatus and $R$. sphaeroides accumulate mainly spheroidene (SE) under anaerobic conditions and spheroidenone (SO) under (semi-) aerobic conditions [27,29-33]. An oxygen-activated spheroidene monooxygenase (CrtA) causes this shift and incorporates a keto-group into SE to form SO [31,32]. The shift from SE to SO helps Rhodobacter to counteract ${ }^{1} \mathrm{O}_{2}$ [34]. The introduced keto-group stabilizes the intramolecular charge transfer state of excited carotenoids by binding to the reaction center of the light-harvesting complex I. Due to its low energy, the intramolecular charge transfer state of carotenoids enables the quenching of ${ }^{1} \mathrm{O}_{2}$ without sacrificing light-harvest. This could explain why different carotenoid-deficient mutants of $R$. sphaeroides 
showed decreased survival rates under photooxidative stress when (hydroxy-) SO amounts were very low [27].

Many small RNAs (sRNAs) are induced by ${ }^{1} \mathrm{O}_{2}$ [35], and for some, the regulatory function could be elucidated. The sRNA-mRNA interactions are often stabilized by the RNA chaperone Hfq, which is another crucial element of the photooxidative stress response in R. sphaeroides [36]. Some of these sRNAs (CcsR1-4, Pos19) are involved in balancing the glutathione pool and in the downregulation of the pyruvate dehydrogenase complex and aerobic electron transport, a primary source of ROS [37,38]. Other sRNAs (SorY, SorX) reduce the metabolic flux into the tricarboxylic acid (TCA) cycle or affect polyamine transport $[39,40]$. a switch from glycolysis to the pentose phosphate cycle and reduced activity of the TCA cycle upon oxidative stress reduce the production of the pro-oxidant NADH and increase production of the protective NADPH. An integrative "omics" approach supports the importance of posttranscriptional regulation in the ${ }^{1} \mathrm{O}_{2}$ response of $R$. sphaeroides [28].

$R$. capsulatus, another member of the Rhodobacteraceae, shares a very similar life style with $R$. sphaeroides, and was also intensely studied with regard to its adaptation to different oxygen- and light conditions [41,42]. Under high oxygen tension, $R$. capsulatus cultures show more pigmentation than $R$. sphaeroides, implying a faster adaptation to phototrophic conditions but a higher risk of ${ }^{1} \mathrm{O}_{2}$ production. However, the response to ${ }^{1} \mathrm{O}_{2}$ has not been elucidated in $R$. capsulatus. In this study, we applied omics approaches to analyze and compare the response of the two Rhodobacter species to photooxidative stress. Although both species share the same habitats, our findings suggest individual strategies to defend against photooxidative stress in addition to a common core response.

\section{Materials and Methods}

\subsection{Bacterial Strains and Growth Conditions}

Rhodobacter strains (Table S1) were cultivated at $32{ }^{\circ} \mathrm{C}$ in minimal medium containing malate as a carbon source [43]. For microaerobic conditions $\left(\sim 25 \mu \mathrm{M} \mathrm{O}_{2}\right)$, cultures were incubated in Erlenmeyer flasks with a culture volume of $80 \%$ and shaking at $140 \mathrm{rpm}$. To cultivate Rhodobacter under aerobic conditions (160-180 $\mu \mathrm{M} \mathrm{O}_{2}$ ), cultures were grown either in baffled flasks with shaking at $140 \mathrm{rpm}$ and a culture volume of $20 \%$, or in flat glass bottles gassed with air. To establish phototrophic growth, airtight flat glass bottles were completely filled with medium and cultures were illuminated continuously with white light $\left(60 \mathrm{~W} \cdot \mathrm{m}^{-2}\right.$; fluorescent tube: Omnilux $\left.18 \mathrm{~W}\right)$. In order to shift Rhodobacter between two different growth conditions, exponentially growing cultures $\left(\mathrm{OD}_{660}\right.$ of $\left.\sim 0.4\right)$ were diluted to an $\mathrm{OD}_{660}$ of 0.2 .

\subsection{Photooxidative Stress Experiments}

Photooxidative stress experiments were carried out as previously described in Glaeser and Klug, 2005 [27]. In short, pigmented cultures from microaerobic cultivation were shifted to aerobic conditions in air-gassed flat glass bottles in the dark. Methylene blue was added at a final concentration of $0.2 \mu \mathrm{M}$. After an $\mathrm{OD}_{660}$ of $\sim 0.4$ was reached, cultures were exposed to $800 \mathrm{~W} \cdot \mathrm{m}^{-2}$ white light to generate ${ }^{1} \mathrm{O}_{2}$ (photooxidative stress).

For zone of inhibition assays, exponentially growing cultures were diluted into soft agar $(0.8 \%$, $w / v)$ and poured onto malate minimal salt medium agar $(1.6 \%, w / v)$. Five microliters of methylene blue $(10 \mu \mathrm{M})$ were spotted onto a filter paper disk, which was placed in the center of the agar plate. Cultures were incubated for $48 \mathrm{~h}$ at $32{ }^{\circ} \mathrm{C}$ under illumination with $20 \mathrm{~W} \cdot \mathrm{m}^{-2}$ white light.

\subsection{Analysis of Pigmentation}

BChl $a$ and carotenoids were extracted and measured as described in Glaeser and Klug, 2005 [27]. Briefly, $1 \mathrm{~mL}$ samples of Rhodobacter cultures were harvested at $17,000 \times g$ for $5 \mathrm{~min}$. Pellets were

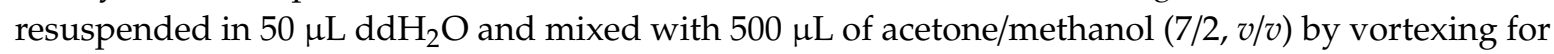
$30 \mathrm{~s}$. Samples were centrifuged at $17,000 \times \mathrm{g}$ for $5 \mathrm{~min}$, and the absorption of the supernatant was 
measured in a Specord 50 Plus spectrometer (Analytik Jena, Jena, Germany), using acetone/methanol $(7 / 2, v / v)$ as a reference. The carotenoid and $\mathrm{BChl} a$ concentrations were calculated from the absorptions at 484 and $770 \mathrm{~nm}$, respectively, with extinction coefficients of $128 \mathrm{mM}^{-1} \cdot \mathrm{cm}^{-1}$ for carotenoids [44] and $76 \mathrm{mM}^{-1} \cdot \mathrm{cm}^{-1}$ for BChl $a$ [45]. Concentrations were normalized to the $\mathrm{OD}_{660}$.

\subsection{Measurement of Reactive Oxygen Species}

Singlet oxygen levels were measured using the fluorescent probe Singlet Oxygen Sensor Green (SOSG, Molecular Probes, Eugene, OR, USA). a SOSG stock solution of $100 \mu \mathrm{M}$ was prepared in HEPES buffer (40 mM, pH 7, 1\% methanol). Six microliters of the SOSG stock solution were added to $114 \mu \mathrm{L}$ culture samples (final SOSG concentration of $5 \mu \mathrm{M}$ ). Technical duplicates were incubated for $30 \mathrm{~min}$ at $32^{\circ} \mathrm{C}$ and $450 \mathrm{rpm}$ in a Vibramax 100 shaker (Heidolph Instruments, Schwabach, Germany). Samples were either kept in the dark or illuminated with $800 \mathrm{~W} \cdot \mathrm{m}^{-2}$ red light. Samples without SOSG served as background controls. Cells were centrifuged at 8,000 rpm for 5 min and resuspended in $100 \mu \mathrm{L}$ HEPES buffer (40 mM, pH 7, 1\% methanol). Fluorescence intensities (excitation $500 \mathrm{~nm}$, emission $532 \mathrm{~nm}$ ) were measured in an Infinite M200 microplate reader (Tecan, Crailsheim, Germany). After subtraction of the background control, fluorescence intensities were normalized to BChl $a$ levels. Ratios between illuminated samples and dark controls were subsequently calculated.

General ROS levels were measured as previously described [43], using the oxidation-sensitive fluorescent probe 2,7-dihydrodichlorofluorescein diacetate $\left(\mathrm{H}_{2} \mathrm{DCFDA}\right.$, Molecular Probes, Eugene, OR, USA). Culture samples of $100 \mu \mathrm{L}$ were incubated at $32{ }^{\circ} \mathrm{C}$ with $\mathrm{H}_{2} \mathrm{DCFDA}$ (final concentration of $10 \mu \mathrm{M}$ ) for $30 \mathrm{~min}$ and shaking at $140 \mathrm{rpm}$ in technical triplicates. a culture sample without $\mathrm{H}_{2} \mathrm{DCFDA}$ served as background control. Fluorescence intensities (excitation 492 nm, emission 525 nm) were measured in an Infinite M200 microplate reader (Tecan, Crailsheim, Germany). After subtraction of the background control, fluorescence intensities were normalized to the $\mathrm{OD}_{660}$.

\subsection{Transcriptome Analysis by RNA-Sequencing}

\subsubsection{Sample Preparation for RNA-seq}

Cultures of R. capsulatus were shifted from microaerobic to aerobic growth in the dark followed by photooxidative stress as described by Berghoff and colleagues [28]. Samples of $20 \mathrm{~mL}$ before (0 min) and after stress (10 $\mathrm{min}$ ) were collected, cooled on ice, and centrifuged at $10,000 \times \mathrm{g}$ for $10 \mathrm{~min}$ at $4{ }^{\circ} \mathrm{C}$. Cell pellets were resuspended in $1 \mathrm{~mL}$ minimal medium and centrifuged at $10,000 \times g$ for $10 \mathrm{~min}$ at $4{ }^{\circ} \mathrm{C}$. RNA was extracted via the hot phenol protocol [46]. The RNA was resolved in RNase-free water (Roth) and treated with DNaseI (Invitrogen, Carlsbad, CA, USA) to remove traces of DNA. a test PCR (rpoZ-for: 5'-GAT GAT CTG CGC GAG CGT CT-3'; rpoZ-rev: 5' -CCT TGC GCG TCC ATC AAT GC-3') was performed to ensure that the RNA was free of DNA. RNA integrity was assessed using the Agilent RNA 6000 Nano Kit on the Agilent 2100 Bioanalyzer (Agilent Technologies, Santa clara, CA, USA) to ensure high quality RNA ( $R I N \geq 9$ ) for downstream processing. rRNA was depleted from $5 \mu \mathrm{g}$ of total RNA using the Ribo-Zero rRNA Removal Kit (Gram-Negative Bacteria, Epicentre Biotechnologies, Madison, WI, USA) as recommended by the manufacturer. One microliter of either 1:10 diluted ERCC ExFold RNA Spike-in Mix 1 or Mix 2 (Ambion, Austin, TX, USA) was added to $1 \mu \mathrm{g}$ of rRNA-depleted RNA. To create 5'-monophosphorylated RNA, rRNA-depleted RNA (including ERCC Spike-in Mixes) was treated with RNA 5' polyphosphatase as recommended by the manufacturer.

\subsubsection{Strand-Specific Library Preparation and Illumina Sequencing}

Strand-specific RNA-seq cDNA library preparation and barcode introduction was based on RNA adapter ligation as described earlier [47]. The quality of the libraries was validated using an Agilent 2100 Bioanalyzer (Agilent Technologies) following the manufacturer's instruction. Cluster generation was performed using the Illumina cluster station. Single-end sequencing on the HiSeq2500 followed a standard protocol. The fluorescent images were processed to sequences and transformed to FastQ 
format using the Genome Analyzer Pipeline Analysis software 1.8.2 (Illumina, San Diego, CA, USA). The sequence output was controlled for general quality features, sequencing adapter clipping, and demultiplexing using the fastq-mcf and fastq-multx tool of ea-utils [48].

\subsubsection{Read Mapping, Bioinformatics and Statistics}

The quality of the sequencing output and potential contamination was analyzed using FastQC (Babraham Bioinformatics, http://www.bioinformatics.babraham.ac.uk/projects/fastqc/). Identified adapter contamination and remaining artificial sequence (barcode) were removed using program fastx_trimmer from the FASTX-210 toolkit version 0.0.13 (http://hannonlab.cshl.edu/fastx_ toolkit/). On the $3^{\prime}$-end, reads were trimmed if the per base Phred score fell short of 20. Trimmed reads with a remaining length $<20$ nucleotides were discarded. All sequenced libraries were mapped to the $R$. capsulatus genome (accession no. NC_014034) and the pRCB133 plasmid (accession no. NC_014035.1) using Bowtie2 (version 2.1.0) in end-to-end alignment mode [49]. After read mapping, the resulting bam files were filtered for uniquely mapped reads using SAMtools (both strands) [50]. The determined uniquely mapped read counts served as inputs to DESeq2 [51] for the pairwise detection and quantification of differential gene expression. For DESeq2 parametrization, we used a beta prior and disabled Cook distance cut off filtering. All other parameters remained unchanged. In addition, RPKM (reads per kilobase max. transcript length per million mapped reads) values were computed for each library from the raw gene counts. The list of DESeq2 determined differentially expressed genes (DEGs) was filtered with a conservative absolute log2 fold change cutoff of at least 1 and a cutoff for a multiple testing corrected $p$-value of at most 0.05 .

\subsubsection{ERCC Spike-in Control Analysis}

To assess the platform dynamic range and the accuracy of fold-change responses, ERCC RNA Spike-in controls were used. Spike-in control sequences were added to the $R$. capsulatus reference genome/annotation prior to read alignment and read counts for Spike-in controls were determined, along with normal gene counts with program htseq-count. Further data analyses and the generation of dose- and fold-change response plots were performed as described by the manufacturer (Ambion, Carlsbad, CA, USA).

\subsubsection{RNA-seq Data Accessibility}

The RNA-seq analysis can be found in Table S2. Raw RNA-seq data have been deposited in NCBI's Gene Expression Omnibus, and are accessible through GEO Series accession number GSE134200.

\subsection{Quantitative RT-PCR}

For quantitative RT-PCR, total RNA was isolated after $10 \mathrm{~min}$ of photooxidative stress as described for RNA-seq. Samples were treated with TURBO DNA-free ${ }^{\mathrm{TM}}$ Kit (Invitrogen, Thermo Fisher Scientific, Schwerte, Germany) to remove DNA contaminations. The Brilliant III Ultra-Fast SYBR Green QRT-PCR Master Mix (Agilent Technologies, Waldbronn, Germany) was applied using $4 \mathrm{ng} \cdot \mu \mathrm{L}^{-1}$ of total RNA per reaction. RT-PCR was performed in a CFX Connect ${ }^{\mathrm{TM}}$ Real-Time System (Bio-Rad). Cycle threshold $(\mathrm{Ct})$ values were determined using the CFX Maestro ${ }^{\mathrm{TM}}$ Software (Bio-Rad, Feldkirchen, Germany), and relative transcript levels calculated according to Pfaffl (2001) [52]. The rpoZ gene was used for normalization. Primers and their amplification efficiencies are listed in Table S3.

\subsection{Protein Sample Preparation and Mass Spectrometry}

Protein sample preparation was performed as previously described [53]. For mass spectrometry (MS) analysis, peptides were eluted from STAGE tips by solvent B ( $80 \%$ acetonitrile, $0.1 \%$ formic acid), dried down in a SpeedVac Concentrator (Thermo Fisher Scientific, Schwerte, Germany) and dissolved in solvent a $(0.1 \%$ formic acid). Peptides were separated using an UHPLC system (EASY-nLC 
1000, ThermoFisher Scientific, Waltham, MA, USA) and $20 \mathrm{~cm}$, in-house packed C18 silica columns (1.9 $\mu \mathrm{m} \mathrm{C18} \mathrm{beads,} \mathrm{Dr.} \mathrm{Maisch} \mathrm{GmbH}$ ) coupled in line to a Q-Exactive HF orbitrap mass spectrometer (ThermoFisher Scientific) using an electrospray ionization source. a gradient of $240 \mathrm{~min}$ was applied using a linearly increasing concentration of solvent $\mathrm{B}(80 \%$ acetonitrile, $0.1 \%$ formic acid) over solvent a ( $0.1 \%$ formic acid) from $5 \%$ to $30 \%$ for $215 \mathrm{~min}$ and from $30 \%$ to $60 \%$ for $5 \mathrm{~min}$, followed by washing with $95 \%$ of solvent B for 5 min and re-equilibration with $5 \%$ of solvent B. Full MS spectra were acquired in a mass range of 300 to $1750 \mathrm{~m} / \mathrm{z}$ with a resolution of 60,000 at $200 \mathrm{~m} / \mathrm{z}$. The ion injection target was set to $3 \times 10^{6}$ and the maximum injection time limited to $20 \mathrm{~ms}$. Ions were fragmented by high-energy collision dissociation (HCD) using a normalized collision energy of 27 and an ion injection target of $5 \times 10^{5}$ with a maximum injection time of $20 \mathrm{~ms}$. The resulting tandem mass spectra (MS/MS) were acquired with a resolution of 15,000 at $200 \mathrm{~m} / \mathrm{z}$ using data dependent mode with a loop count of 15 (top 15). MS raw data were processed by MaxQuant (1.5.3.12) [54] using the Uniprot database for R. capsulatus containing 4290 entries (release date July 2016). The following parameters were used for data processing: maximum of two miss cleavages, mass tolerance of $4.5 \mathrm{ppm}$ for main search, trypsin as digesting enzyme, carbamidomethylation of cysteines as fixed modification, oxidation of methionine, and acetylation of the protein $\mathrm{N}$-terminus as variable modifications. For protein quantification, the LFQ function of MaxQuant was used. Peptides with a minimum of seven amino acids and at least one unique peptide were required for protein identification. Only proteins with at least two peptides and at least one unique peptide were considered to have been identified and were used for further data analysis. LFQ intensities for all identified proteins can be found in Table S4.

\subsection{Search for Orthologous Rhodobacter Genes and Synteny Analysis}

To find orthologous genes in R. capsulatus and R. sphaeroides, the Genome Gene Best Homologs tool from the IMG web resources was used [55]. The pBLAST-based search of orthologous genes used a 30\% amino acid identity as a cutoff value for homology. $\mathrm{PHYRE}^{2}$ was applied for a structural homology search [56]. Synteny analysis was performed using EDGAR 2.3, a software platform for comparative gene content analyses [57].

\subsection{Gene Ontology Enrichment Analysis}

Significantly enriched functional groups were determined with the program Cytoscape version 3.6.0 [58] according to Gene Ontology (GO) terms using the BiNGO tool [59]. Overrepresented GO categories in the data sets were determined with a hypergeometric test with Benjamini-Hochberg false discovery rate correction and a significance level of 0.05 . The whole $R$. capsulatus genome served as a reference. The selected ontology file was gb.obo, format-version 1.2, released 06/10/2017 [60,61]. The resulting networks were searched for overrepresented GO categories.

\section{Results}

\subsection{Adaptation of R. sphaeroides and R. capsulatus to Different Growth Conditions}

Based on the different pigment content of the two Rhodobacter species, we hypothesized differences in their adaptation to phototrophic growth. When cultures of the two species were kept under microaerobic conditions in the dark, the growth behavior was nearly identical (doubling time $\mathrm{t}_{\mathrm{d}}$ of $4 \mathrm{~h}$ $\pm 3 \mathrm{~min}$ for $R$. capsulatus and $4 \mathrm{~h} 10 \mathrm{~min} \pm 15 \mathrm{~min}$ for $R$. sphaeroides, Figure $1 \mathrm{~A}$ ). a shift from high oxygen to phototrophic conditions with $60 \mathrm{~W} \cdot \mathrm{m}^{-2}$ white light revealed a remarkably faster adaption process for $R$. capsulatus, i.e., entering the exponential growth after the shift took $\sim 4 \mathrm{~h}$ for $R$. capsulatus but $\sim 21 \mathrm{~h}$ for $R$. sphaeroides (Figure 1B). As seen by the doubling time, R. capsulatus also grew faster in exponential phase under phototrophic conditions than $R$. sphaeroides ( $\mathrm{t}_{\mathrm{d}}$ of $3 \mathrm{~h} 35 \mathrm{~min} \pm 4 \mathrm{~min}$ for $R$. capsulatus and $6 \mathrm{~h} 50 \mathrm{~min} \pm 30 \mathrm{~min}$ for $R$. sphaeroides). This supported our hypothesis that the higher pigment content of $R$. capsulatus would allow a faster switch to occur to phototrophic growth. Interestingly, 
carotenoids (especially SE and SO) strongly contributed to the growth benefit of R. capsulatus, as shown by experiments with transposon mutants lacking these carotenoids (Figure S1).
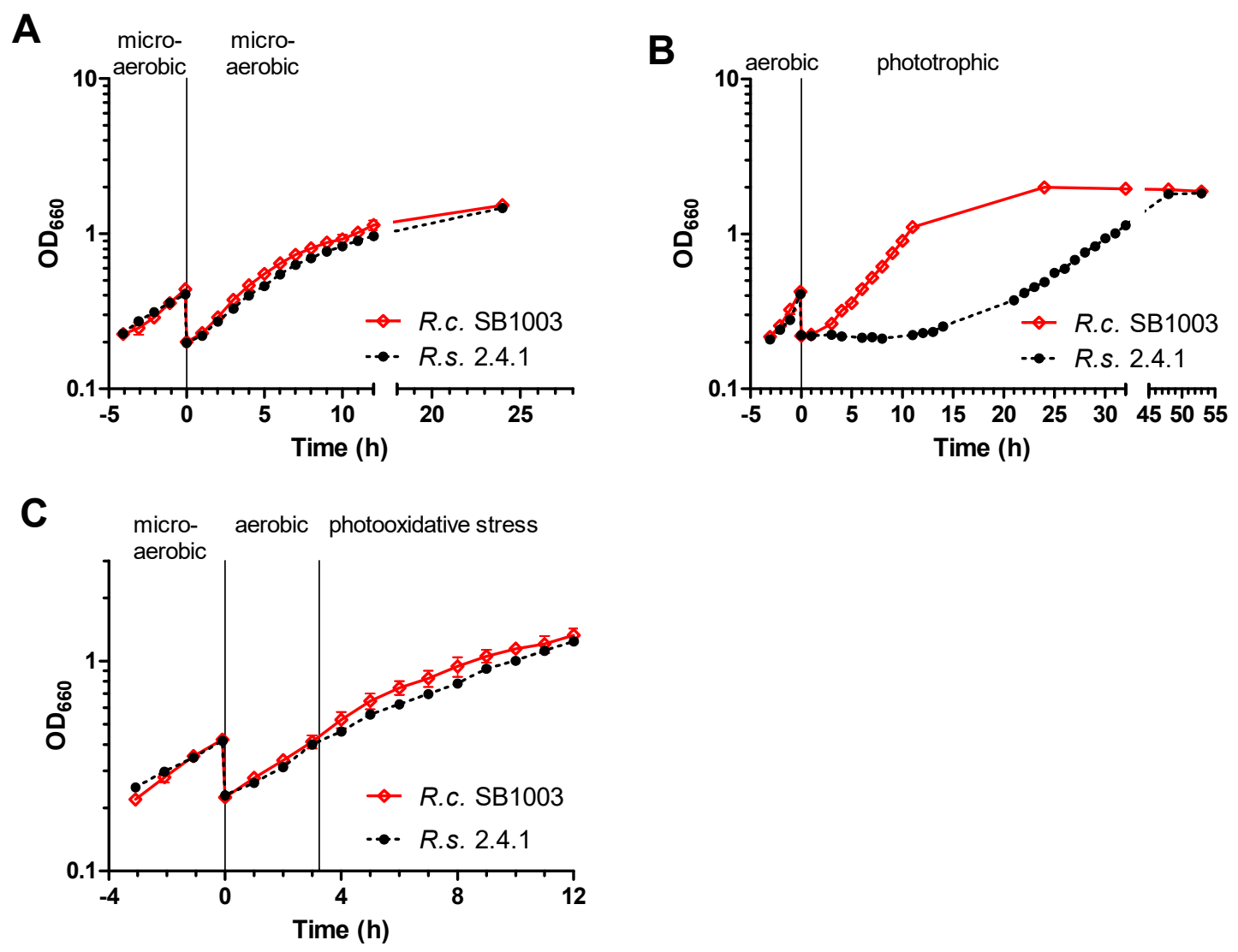

Figure 1. Growth of R. capsulatus and R. sphaeroides under different oxygen and light conditions. Exponential phase cultures of R. capsulatus (R.c. SB1003) and R. sphaeroides (R.s. 2.4.1) were diluted to an $\mathrm{OD}_{660}$ of 0.2 at time point $0 \mathrm{~h}$. The $\mathrm{OD}_{660}$ was plotted semi-logarithmically against the time. Data points represent the mean of biological triplicates and error bars depict the standard deviation (standard deviations might not be visible if they are too small). (A) Microaerobically growing cultures. (B) Aerobically growing cultures shifted to phototrophic growth. (C) Microaerobically growing cultures were exposed to photooxidative stress when an $\mathrm{OD}_{660}$ of $\sim 0.4$ was reached. Figure $\mathrm{S} 2$ shows growth under dark and light conditions with or without methylene blue.

We also asked the question of how a strong increase of photooxidative stress caused by ${ }^{1} \mathrm{O}_{2}$ would affect growth of the two Rhodobacter species. To test this, pigmented cultures (after microaerobic cultivation) were cultivated under aerobic conditions in the dark and shifted to high light conditions $\left(800 \mathrm{~W} \cdot \mathrm{m}^{-2}\right)$ in the presence of methylene blue $(0.2 \mu \mathrm{M})$ when an $\mathrm{OD}_{660}$ of 0.4 was reached. These conditions were previously shown to produce ${ }^{1} \mathrm{O}_{2}$ and to induce a specific response in R. sphaeroides [27,28]. Importantly, neither methylene blue in the dark nor high light without methylene blue resulted in a strong growth retardation (Figure S2). After initiating photooxidative stress, $R$. capsulatus showed faster growth than $R$. sphaeroides, but slowed down earlier. As a consequence, both strains reached the same $\mathrm{OD}_{660}$ after $12 \mathrm{~h}$ (Figure $1 \mathrm{C}$ ).

Although a stronger pigmentation of $R$. capsulatus cultures under high oxygen tension compared to $R$. sphaeroides was obvious, we wanted to quantify the differences and also analyze the ratio of carotenoids and bacteriochlorophylls throughout growth at different conditions. While bacteriochlorophyll functions as a photosensitizer that promotes the production of ${ }^{1} \mathrm{O}_{2}$, carotenoids can quench ${ }^{1} \mathrm{O}_{2}$, and are thus part of the defense system against ${ }^{1} \mathrm{O}_{2}$. In general, $R$. capsulatus showed a higher amount of bacteriochlorophyll $a(\mathrm{Bchl} a)$ and carotenoids, e.g., under microaerobic conditions (Figure S3) at 
an $\mathrm{OD}_{660}$ of $\sim 0.4:$ R. capsulatus had $\sim 3.0 \mu \mathrm{M}$ per $\mathrm{OD}_{660}$ carotenoids and $\sim 2.8 \mu \mathrm{M}$ per $\mathrm{OD}_{660} \mathrm{Bchl} a$, whereas $R$. sphaeroides had $\sim 0.7 \mu \mathrm{M}$ per $\mathrm{OD}_{660}$ carotenoids and $\sim 2.0 \mu \mathrm{M}$ per $\mathrm{OD}_{660} \mathrm{Bchl} a$. After a shift to phototrophic growth, carotenoid and Bchl $a$ levels steadily increased in $R$. capsulatus, reaching levels that were much higher than under aerobic conditions (Figure 2A). Since R. sphaeroides stopped growing after this transition for nearly $13 \mathrm{~h}$, the carotenoid and Bchl $a$ levels stayed low during this time period and increased only slowly. Thirty-two hours after the shift, carotenoid and Bchl $a$ levels were about 3.6-fold and 4.1-fold higher, respectively, in R. capsulatus (Figure 2A). After a shift from low to high oxygen tension and addition of methylene blue in the dark, the pigment level steadily dropped in both strains (Figure 2B). When illumination was started to generate ${ }^{1} \mathrm{O}_{2}$, the $\mathrm{Bchl} a$ level dropped further. The carotenoid level in $R$. capsulatus, however, remained fairly constant $\left(\sim 1.4 \mu \mathrm{M}\right.$ per $\left.\mathrm{OD}_{660}\right)$, with a small peak $\left(\sim 1.6 \mu \mathrm{M}\right.$ per $\left.\mathrm{OD}_{660}\right)$ after four hours of stress. By contrast, $R$. sphaeroides showed a steady decline of carotenoids.
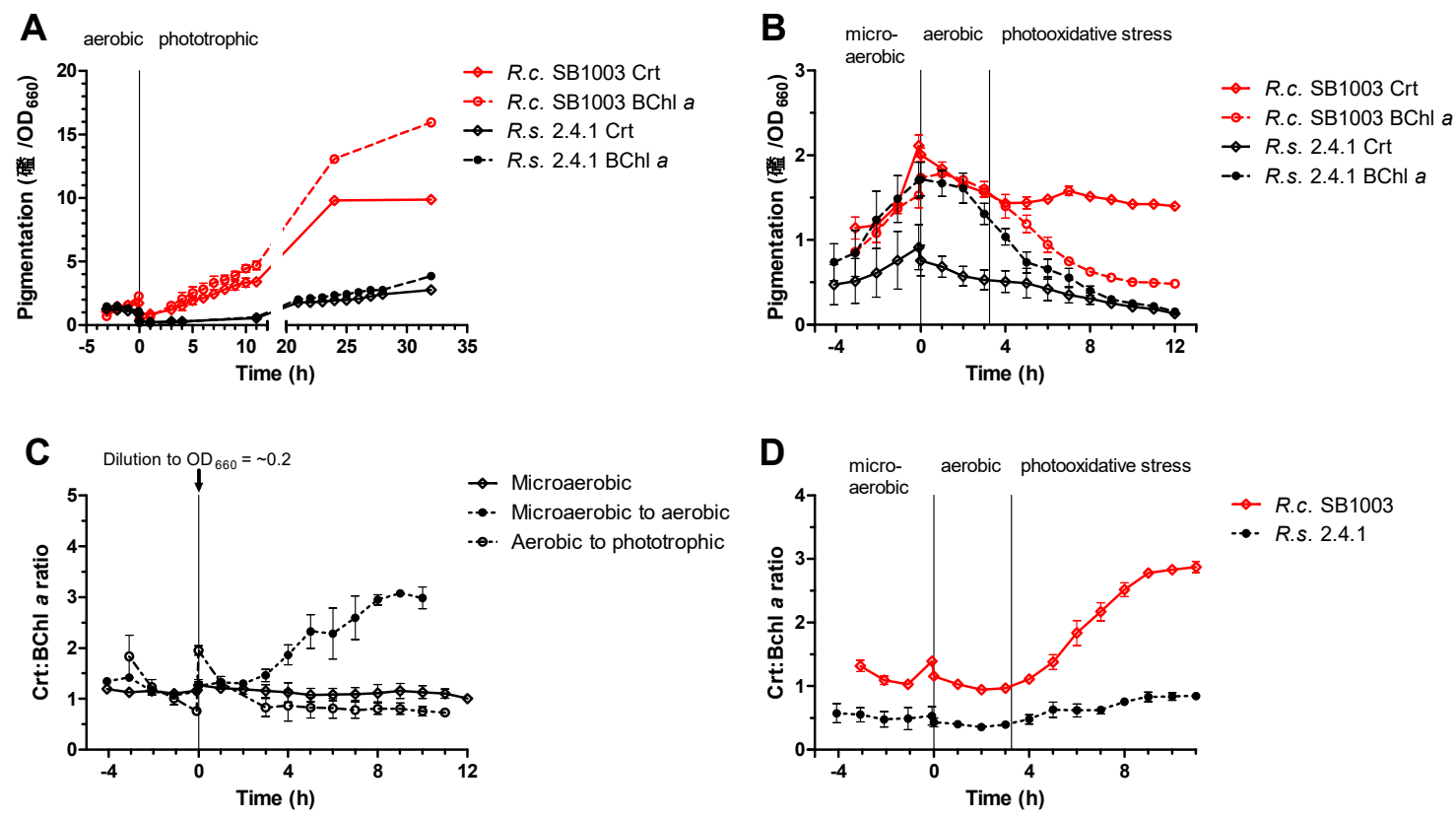

Figure 2. R. capsulatus has a stronger pigmentation and a higher carotenoid to bacteriochlorophyll $a$ ratio than $R$. sphaeroides. Cultures in the exponential phase were diluted to an $\mathrm{OD}_{660}$ of 0.2 at time point $0 \mathrm{~h}$. The content of carotenoids (Crt) and bacteriochlorophyll $a(\mathrm{Bchl} a)$ was normalized to the respective $\mathrm{OD}_{660}$-values and plotted against the time for (A) aerobically growing cultures shifted to phototrophic growth, and (B) microaerobically growing cultures shifted to aerobic dark conditions followed by exposure to photooxidative stress. The Crt:Bchl $a$ ratio was plotted against the time for (C) $R$. capsulatus either continuously grown under microaerobic conditions or shifted to different oxygen and light conditions, and for (D) R. capsulatus and R. sphaeroides after a shift from microaerobic to aerobic dark conditions followed by photooxidative stress. Data points represent the mean of biological triplicates and error bars depict the standard deviation (standard deviations might not be visible if they are too small).

Not only the total amount of pigments may be important for adaptation of Rhodobacter species to changing conditions, but also the ratio of the ${ }^{1} \mathrm{O}_{2}$-quenching carotenoids (Crt) to the ${ }^{1} \mathrm{O}_{2}$-producing $\mathrm{BChl} a$. In R. capsulatus, the $\mathrm{Crt}: \mathrm{BChl} a$ ratio did not change much during continuous cultivation under microaerobic conditions (ratio of $~ 1.1$ ) or after a shift from aerobic to phototrophic conditions (ratio of $\sim 0.8$; Figure 2C). However, a shift from microaerobic to aerobic conditions resulted in a strong increase of the Crt:Bchl $a$ ratio from $\sim 1.2$ to $\sim 3.0$ in $R$. capsulatus (Figure 2C). Figure 2D compares the change in the $\mathrm{Crt}: \mathrm{Bchl} a$ ratio between $R$. sphaeroides and $R$. capsulatus upon exposure to ${ }^{1} \mathrm{O}_{2}$. The ratios remained fairly constant in both species during microaerobic growth and also after the shift to aerobic 
dark conditions in the presence of methylene blue. The ratios were $\sim 1.1$ in $R$. capsulatus and $\sim 0.5$ in R. sphaeroides. After the start of illumination and the production of ${ }^{1} \mathrm{O}_{2}$, the $\mathrm{Crt}: \mathrm{Bchl} a$ ratio increased in $R$. capsulatus from $\sim 1.1$ to nearly 3.0. In $R$. sphaeroides this ratio was below one under all conditions, and only increased from $\sim 0.5$ to $\sim 0.8$ after the initiation of photooxidative stress.

\subsection{Generation of ROS in R. sphaeroides and R. capsulatus upon Photooxidative Stress}

To see whether the different $\mathrm{Crt}: \mathrm{BChl} a$ ratios observed in the two Rhodobacter species under photooxidative stress conditions (Figure 2D) would affect ${ }^{1} \mathrm{O}_{2}$ levels, the fluorescent probe Singlet Oxygen Sensor Green (SOSG) was used for in vivo ${ }^{1} \mathrm{O}_{2}$ measurements. Since white light itself can affect SOSG fluorescence, red light was used for illumination [62]. In cell-free reactions, the combination of oxygen, red light, and methylene blue caused enhanced SOSG fluorescence due to photosensitized formation of ${ }^{1} \mathrm{O}_{2}$ (Figure S4). When pigmented cultures were incubated under aerobic conditions in the presence of methylene blue, the ratio of SOSG fluorescence between illuminated samples and dark controls was significantly higher for R. sphaeroides than for R. capsulatus (Figure 3A), indicating enhanced ${ }^{1} \mathrm{O}_{2}$ levels in $R$. sphaeroides. In addition, general $\mathrm{ROS}$ formation was measured by applying 2,7-dihydrodichlorofluorescein diacetate $\left(\mathrm{H}_{2} \mathrm{DCFDA}\right)$ before and after starting the white light illumination of aerobic cultures in the presence of methylene blue. The fluorogenic probe $\mathrm{H}_{2} \mathrm{DCFDA}$ is mainly specific for hydrogen peroxide, peroxynitrite anions, and peroxyl radicals [63], ROS that are partly generated downstream of ${ }^{1} \mathrm{O}_{2}[15,64]$. An increase in DCF fluorescence indicates elevated ROS levels. We found significant differences in fluorescence levels between the two species before and $10 \mathrm{~min}$ after initiating photooxidative stress (Figure 3B). The relative fluorescence intensity indicated higher ROS levels in R. sphaeroides compared to R. capsulatus by a factor of 1.6 and 1.5 for 0 and $10 \mathrm{~min}$ of photooxidative stress, respectively (Figure $3 B$ ).

A

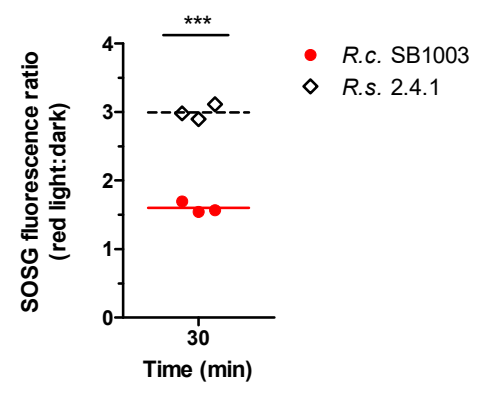

B

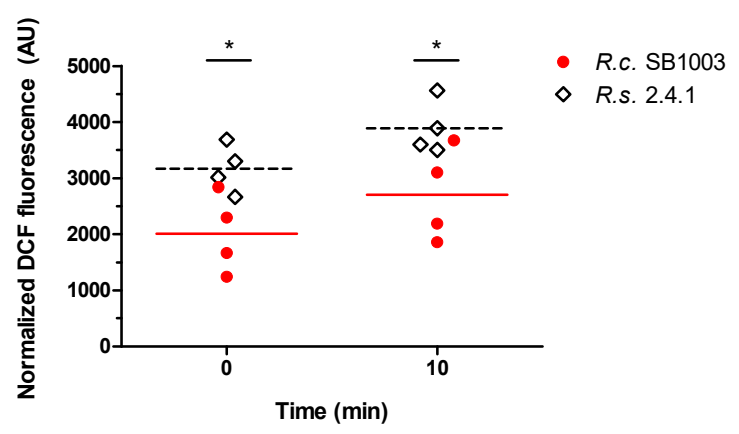

Figure 3. Determination of intracellular ${ }^{1} \mathrm{O}_{2}$ and ROS levels in $R$. capsulatus and R. sphaeroides under photooxidative stress conditions. (A) The fluorogenic probe SOSG was used for ${ }^{1} \mathrm{O}_{2}$ detection. Fluorescence intensities were normalized to BChl $a$ levels. Ratios between illuminated samples (800 W. $\mathrm{m}^{-2}$ red light) and dark controls were calculated. (B) The fluorogenic probe $\mathrm{H}_{2} \mathrm{DCFDA}$ was used for ROS detection. Fluorescence intensities were normalized to the $\mathrm{OD}_{660}$ and displayed in arbitrary units (AU). Data points indicate individual measurements and bars represent the mean. Two-way ANOVA followed by Bonferroni posttest was used to compare results from $R$. capsulatus (R.c. SB1003) and R. sphaeroides (R.s. 2.4.1) (* $p$-value $<0.05,{ }^{* * *} p$-value $\left.<0.001\right)$.

3.3. The rpoE-chrR Locus of R. capsulatus Shows a Unique Genetic Context in Comparison to Other Bacteria within the Rhodobacteraceae

Detailed work in $R$. sphaeroides identified the sigma factor RpoE as the master regulator of the response to ${ }^{1} \mathrm{O}_{2}[1,65]$. RpoE is primarily controlled by its cognate antisigma factor ChrR, but full activation of RpoE requires the RpoE regulon members RSP_1090/91 (putative cyclopropane/cyclopropene fatty acid synthesis proteins) and the cyclopropane-fatty-acyl-phospholipid synthase CfaS [22,23]. In addition, DegS and RseP homologous proteases are involved in the degradation of ChrR [22]. In R. sphaeroides, the RSP_1090/91 genes are located immediately upstream of the rpoE-chrR 
locus, a genetic arrangement that is conserved among many bacteria within the Rhodobacteraceae (e.g., Roseobacter denitrificans, Dinoroseobacter shibae, Jannaschia rubra, Ruegeria litorea, and Oceanicola litoreus). Interestingly, RpoE and ChrR homologs were not found in R. capsulatus using simple sequence alignment tools, but were revealed here by a structural homology search using PHYRE ${ }^{2}$ [56]. The RpoE proteins of $R$. sphaeroides and $R$. capsulatus only share $24 \%$ identity, but the confidence in the PHYRE ${ }^{2}$ structural homology analysis is high (99.9\%). Importantly, the gene adjacent to the rpoE gene of R. capsulatus encodes a putative antisigma factor with $13 \%$ identity to ChrR (confidence of $99.4 \%$ ). Although the identity values are relatively low, the high confidence in the PHYRE ${ }^{2}$ analysis strongly suggests that $R$. capsulatus has true RpoE (RCAP_rcc00699) and ChrR (RCAP_rcc00698) homologs. Moreover, and similar to R. sphaeroides, the rpoE-chrR locus of $R$. capsulatus is induced by ${ }^{1} \mathrm{O}_{2}$, as revealed by RNA-seq (Figure 4 and Table 1). However, microsynteny analysis using EDGAR 2.3 [57] showed that the genetic context of the rpoE-chrR locus in R. capsulatus is different from R. sphaeroides (Figure 4). The RpoE-dependent operon RSP_1087-1091, which is located upstream of rpoE-chrR in R. sphaeroides, cannot be found next to rpoE-chrR in R. capsulatus. Moreover, respective homologs seem to be completely absent from the $R$. capsulatus genome (Table 1 ). Instead, the rpoE-chrR locus is located next to an operon, which encodes the glutathione peroxidase BsaA1, the cryptochrome/photolyase CryB, and two hypothetical proteins. All four genes are clearly induced by ${ }^{1} \mathrm{O}_{2}$ (Figure 4). Interestingly, cryB belongs to the $\mathrm{RpoH}_{\mathrm{II}}$ regulon in $R$. sphaeroides [66]. Microsynteny analysis further revealed that rpoE-chrR is in close proximity to the photosynthetic gene cluster of $R$. capsulatus (bch and puf genes in Figure 4). This genetic arrangement cannot be found in closely related members within the Rhodobacteraceae (155 genomes analyzed in total), and it remains speculative whether this unique gene colocalization is purely coincidental or represents a strong functional relationship between photosynthesis and the response to ${ }^{1} \mathrm{O}_{2}$.

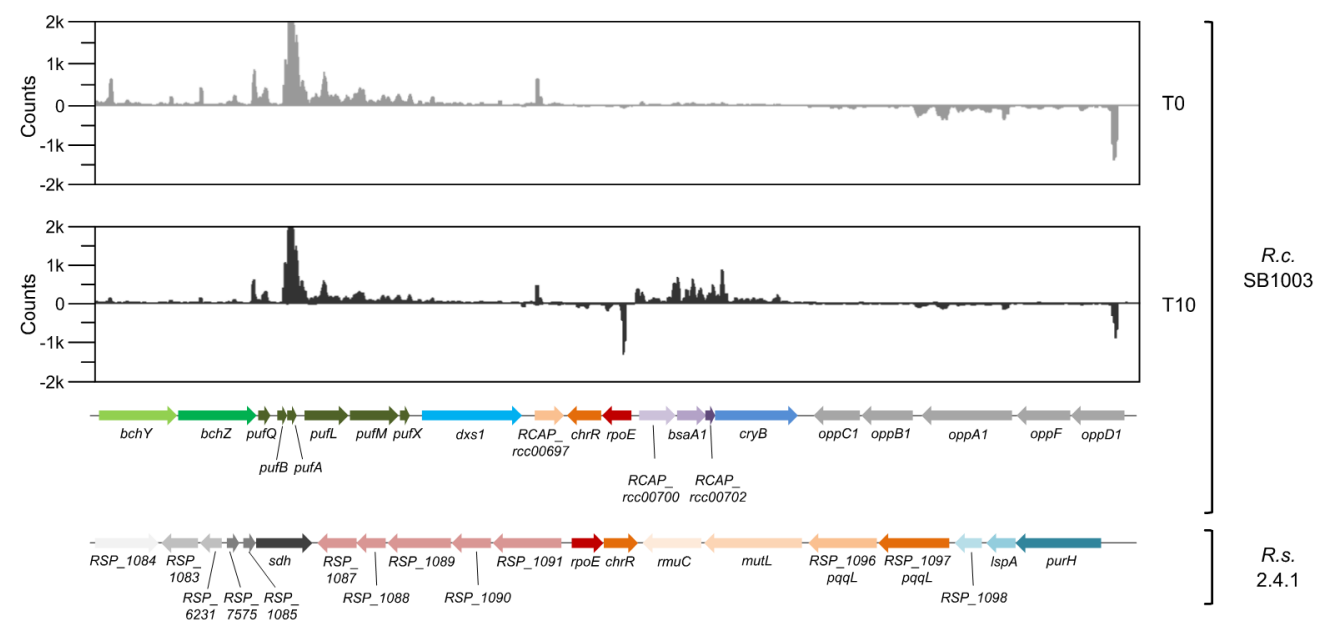

Figure 4. Microsynteny analysis of the rpoE-chrR locus in R. capsulatus and R. sphaeroides. The two upper panels show normalized read count distributions of a representative RNA-seq experiment with R. capsulatus (R.c. SB1003) before (T0) and $10 \mathrm{~min}$ after the onset of photooxidative stress (T10). The lower panels show the microsynteny analysis of the rpoE-chrR locus in $R$. capsulatus and its homologous genes in R. sphaeroides (R.s. 2.4.1). Homologs are indicated by identical colors. 
Table 1. Transcriptome changes upon photooxidative stress of the RpoE regulon in $R$. sphaeroides compared to homologs in $R$. capsulatus.

\begin{tabular}{|c|c|c|c|c|c|}
\hline $\begin{array}{l}\text { R. sphaeroides } \\
\text { Gene }\end{array}$ & Description & $\log _{2} \mathrm{FC}^{1}(7 \mathrm{~min})$ & $\log _{2} \mathrm{FC}^{1}(45 \mathrm{~min})$ & $\begin{array}{l}\text { R. capsulatus } \\
\text { Gene }^{2}\end{array}$ & $\log _{2} F C^{1}(10 \mathrm{~min})$ \\
\hline RSP_1092 rpoE & RNA polymerase sigma-70 factor & $2.2 * *$ & $2.0^{* * *}$ & $\begin{array}{l}\text { RCAP_rcc00699 } \\
\text { rpoE }\end{array}$ & $3.7 * * *$ \\
\hline RSP_1093 chrR & Antisigma factor $\mathrm{ChrR}$ & 2.0 ** & $2.2 * * *$ & $\begin{array}{c}\text { RCAP_rcc00698 } \\
\text { chrR }\end{array}$ & $3.4^{* * *}$ \\
\hline RSP_2144 cfaS & $\begin{array}{l}\text { Cyclopropane-fatty-acyl -phospholipid } \\
\text { synthase CfaS }\end{array}$ & $1.4^{*}$ & $1.0^{* * *}$ & $\begin{array}{l}\text { RCAP_rcc00273 } \\
\text { rsmB1 }\end{array}$ & 0.3 \\
\hline RSP_2143 phrA & DNA photolyase & $1.6^{* *}$ & $1.5^{* * *}$ & $\begin{array}{l}\text { RCAP_rcc02958 } \\
\text { phrB }\end{array}$ & $2.7^{* * *}$ \\
\hline RSP_1091 & $\begin{array}{l}\text { Putative cyclopropane or cyclopropene } \\
\text { fatty acid synthesis protein }\end{array}$ & $2.2^{* * *}$ & $2.0 * * *$ & No homolog & \\
\hline RSP_1090 & $\begin{array}{l}\text { Putative cyclopropane/cyclopropene fatty } \\
\text { acid synthesis protein }\end{array}$ & 2.4 & $1.9^{* * *}$ & No homolog & \\
\hline RSP_1089 & Sugar/cation symporter, GPH family & $1.9 *$ & $1.8^{* * *}$ & No homolog & \\
\hline RSP_1088 & Hypothetical protein & $1.1^{*}$ & $0.8^{* *}$ & No homolog & \\
\hline RSP_1087 & $\begin{array}{l}\text { Short-chain dehydrogenase/reductase } \\
\text { family member }\end{array}$ & 0.9 & $0.7^{* *}$ & No homolog & \\
\hline $\begin{array}{c}\text { RSP_0601 } \\
\text { rpoH } H_{I I}\end{array}$ & RNA polymerase sigma factor & $2.0 *$ & $2.1 *$ & $\begin{array}{c}\mathrm{RCAP}_{2} \mathrm{rcc} 00458 \\
\text { rpoH }_{\text {II }}{ }^{3}\end{array}$ & $2.1^{* * *}$ \\
\hline RSP_1409 & Beta-Ig-H3/fasciclin & 2.8 ** & $4.5^{*}$ & No homolog & \\
\hline RSP_1852 folE2 & Hypothetical protein & $2.2 * * *$ & $2.3 * * *$ & $\begin{array}{l}\text { RCAP_rcc01493 } \\
\text { folE2 }\end{array}$ & $3.3 * * *$ \\
\hline RSP_0296 cycA & Cytochrome c2 & -0.3 & $0.5^{* *}$ & $\begin{array}{l}\text { RCAP_rcc01240 } \\
\text { cycA1 }\end{array}$ & 0.2 \\
\hline RSP_3336 & $\begin{array}{l}\text { ABC spermidine/putrescine transporter, } \\
\text { inner membrane subunit }\end{array}$ & 0.0 & $0.2 *$ & $\begin{array}{l}\text { RCAP_rcc01895 } \\
\text { potH1 }\end{array}$ & $-0.6^{*}$ \\
\hline RSP_6222 & Hypothetical protein & 0.1 & 0.3 & No homolog & \\
\hline
\end{tabular}

${ }^{1}$ It is indicated whether $\log _{2}$ fold changes ( $\log _{2}$ FC; stressed versus unstressed) were statistically significant $\left({ }^{*} p\right.$-value $<0.05,{ }^{* *} p$-value $<0.01$, and ${ }^{* * *} p$-value $\left.<0.001\right)$. Data for $R$. sphaeroides were retrieved from Berghoff and colleagues [28]. ${ }^{2}$ Homologs found either by pBLAST (30\% protein identity) or PHYRE $^{2} .{ }^{3}$ Annotated as $r p o H_{I}$ in public databases.

\subsection{Transcriptome Analysis of the Response to Singlet Oxygen in R. capsulatus}

To learn more about the response to ${ }^{1} \mathrm{O}_{2}$ in $R$. capsulatus, RNA-seq was performed for samples collected before (T0) and $10 \mathrm{~min}$ after the onset of ${ }^{1} \mathrm{O}_{2}$ stress (T10). The reproducibility of biological replicates is shown by correlation analysis with highly significant Pearson's $r$-values of $\geq 0.985$ for all possible interreplicate comparisons (Figure S5). Principal component analysis (PCA) further revealed a clear separation between T0 and T10 samples along the first dimension (Figure S6A). In total, 3441 transcripts were quantified in the RNA-seq analysis. Four hundred and seventy-one transcripts were up- and 261 transcripts were down-regulated upon ${ }^{1} \mathrm{O}_{2}$ stress $\left(\log _{2}\right.$ fold change $\geq 1$ or $\leq-1$ and $p$-value $<0.05$ ). To validate the RNA-seq approach for $R$. capsulatus and to further confirm the microarray results for $R$. sphaeroides [28], quantitative RT-PCR (qRT-PCR) was performed for selected genes. The qRT-PCR data were in good agreement with both RNA-seq and microarray results (Figure 5). However, for $c b b M$, gltD, cysP, crtI, and cbiX, transcript levels were only increased in R. capsulatus. In $R$. sphaeroides, three independent primer pairs were unable to detect $c b i X$ transcripts. 


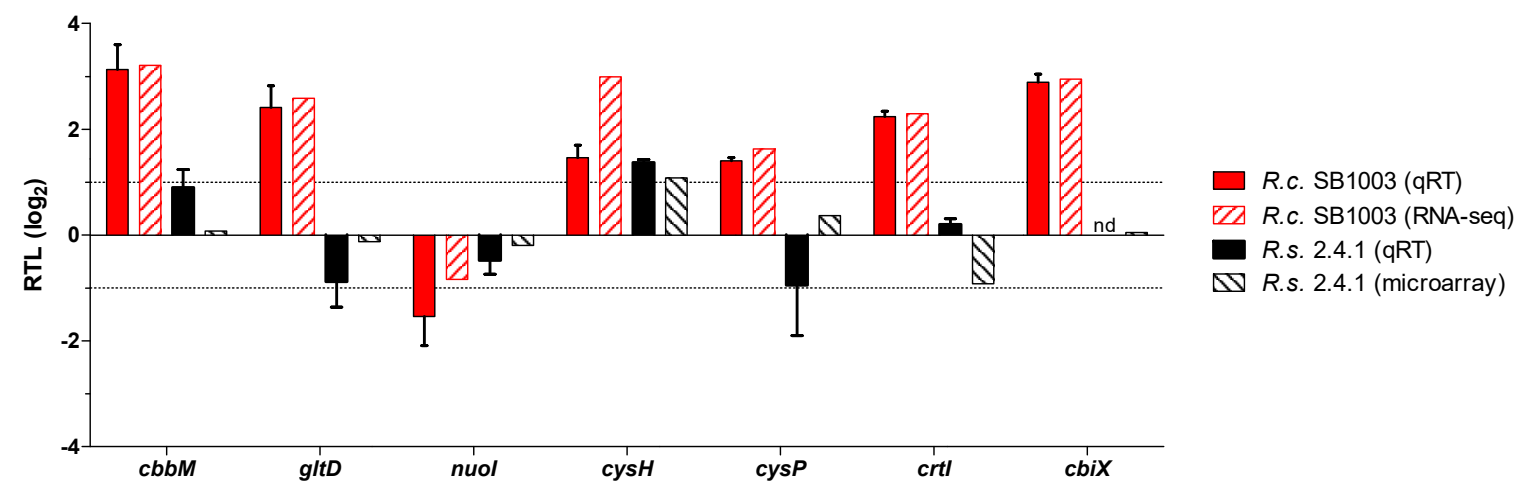

Figure 5. Gene expression changes for selected genes upon photooxidative stress in Rhodobacter. Relative transcript levels (RTL) were calculated after the onset of photooxidative stress in comparison to a non-stressed control in R. capsulatus (R.c. SB1003) and R. sphaeroides (R.s. 2.4.1). RNA-seq (this study) and microarray data [28] are shown for comparison. For qRT-PCR (qRT), bars represent the mean of biological triplicates, and error bars depict the standard deviation. The $c b i X$ transcript was not detected (nd) in R. sphaeroides.

From $R$. sphaeroides, it is known that 13 out of 15 genes of the RpoE regulon are induced by ${ }^{1} \mathrm{O}_{2}$ (Table 1; [28]). In R. capsulatus, protein homologs were only found for seven of the 15 RpoE regulon members, which applies to RpoE, ChrR, photolyase PhrA (PhrB), sigma factor $\mathrm{RpoH}_{\mathrm{II}}$, cytochrome c2 CycA (CycA1), a polyamine transporter subunit (PotH1), and cyclohydrolase FolE2 (RCAP_rcc01493) (Table 1). It is worth noting that the aforementioned $R$. capsulatus sigma factors $\mathrm{RpoH}_{\mathrm{I}}$ and $\mathrm{RpoH}_{\mathrm{II}}$ are wrongly annotated in public databases: our analyses (see below) clearly show that RCAP_rcc00458

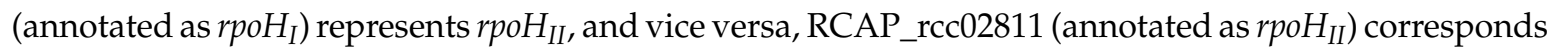
to $r p o H_{I}$ from $R$. sphaeroides. Thus, we refer to RCAP_rcc00458 as rpoH $H_{I I}$ and to RCAP_rcc02811 as $r p o H_{I}$. Among the seven homologs of the $\mathrm{RpoE}$ regulon, only $r p o E, c h r R, p h r B, r p o H_{I I}$, and folE2 were induced upon ${ }^{1} \mathrm{O}_{2}$ stress in $R$. capsulatus, indicating that similarities are probably limited to the most important features, which has also been observed for Roseobacter denitrificans [67]. One of the conserved ${ }^{1} \mathrm{O}_{2}$-related features includes sigma factor $\mathrm{RpoH}_{\mathrm{II}}$, which shares a partially overlapping regulon with heat-shock sigma factor $\mathrm{RpoH}_{\mathrm{I}}$ in $R$. sphaeroides $[10,19,20]$. In contrast to rpoE-chrR, the genetic context of both $r p o H_{I}$ and $r p o H_{I I}$ is partly conserved between $R$. sphaeroides and $R$. capsulatus (Figure 6A,B). From $R$. sphaeroides it is known that $\mathrm{RpoH}_{\mathrm{II}}$ is more important for ${ }^{1} \mathrm{O}_{2}$ stress resistance than $\mathrm{RpoH}_{\mathrm{I}}$ [20]; the same was observed here for $R$. capsulatus (Figure 6C).

To identify the most prominently enriched functional groups in $R$. capsulatus, we conducted a Gene Ontology (GO) term enrichment analysis using BiNGO in Cytoscape [58,59] for the 100 transcripts with the strongest increase. Transcripts contributing to oxidation-reduction processes were significantly increased and formed the largest group (24 transcripts; Figure 7). Furthermore, we could identify several stress-related functional groups. The first group comprises nine transcripts encoding proteins with a role in protein turnover and repair, which applies to the peptide methionine sulfoxide reductases MsrA1, MsrA2, MsrB1, and MsrB2, the chaperones GroS and GroL, and the peptidases/proteases Dcp, TldD, and RCAP_rcc03333 (Figure 7). The second group comprises five transcripts encoding proteins with a known role in the (photo-) oxidative stress response, including RpoE and ChrR, RpoE-dependent GTP cyclohydrolase FolE2, peroxidase BsaA1, and glutathione-disulfide reductase Gor (Figure 7). The third and last group is formed by five transcripts encoding proteins with a function in DNA damage repair, which applies to photolyases PhrB and CryB, two components of the UvrABC complex, and the A/G-specific adenine glycosylase MutY (Figure 7). 
A
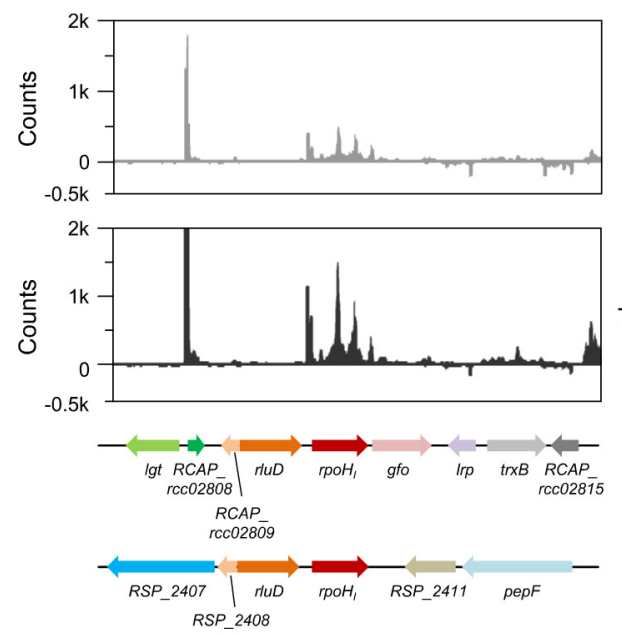

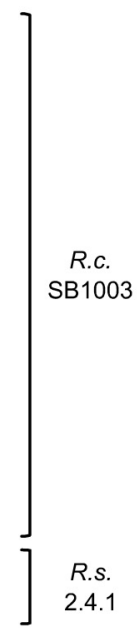

C

- R.c. SB1003

口 R.c. $\triangle$ rpoH

$\Delta$ R.c. $\Delta r p o H_{1}$

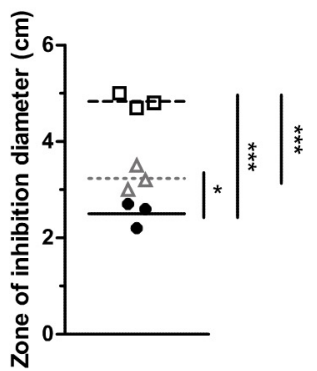

B

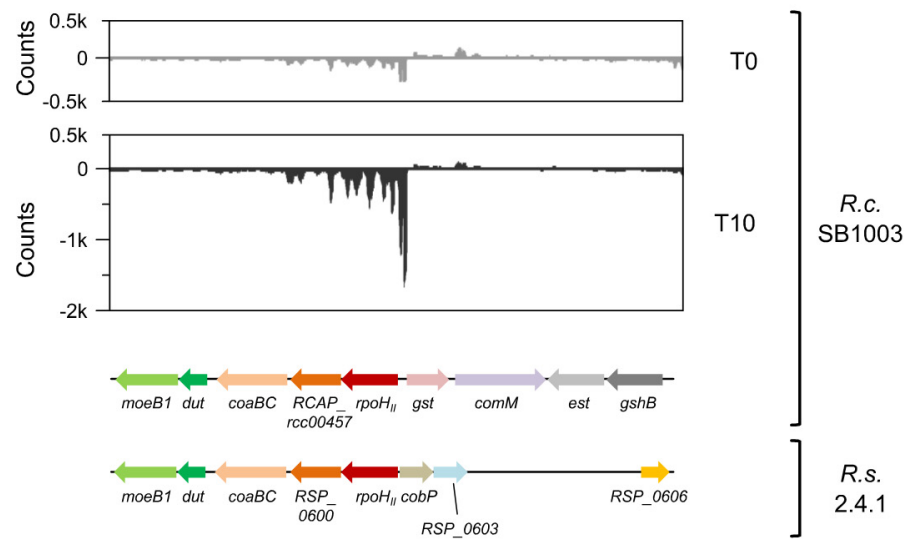

Figure 6. Analysis of $r p o H_{I}$ and $r p o H_{I I}$ in $R$. capsulatus. RNA-seq and microsynteny analysis for (A) $r p o H_{I}$ and (B) $r p o H_{I I}$ in $R$. capsulatus. The two upper panels show read count distributions of a representative RNA-seq experiment with $R$. capsulatus (R.c. SB1003) before (T0) and $10 \mathrm{~min}$ after the onset of photooxidative stress (T10). The lower panels show the microsynteny analysis of the rpoH locus in R. capsulatus and its homologous genes in R. sphaeroides (R.s. 2.4.1). Homologs are indicated by identical colors. (C) Zone of inhibition assay showing the sensitivity of $R$. capsulatus strains to photooxidative stress. Data points indicate individual measurements and bars represent the mean. One-way ANOVA followed by Bonferroni posttest was used to compare results from different $R$. capsulatus strains $\left({ }^{*} p\right.$-value $<0.05,{ }^{* * *} p$-value $\left.<0.001\right)$. 

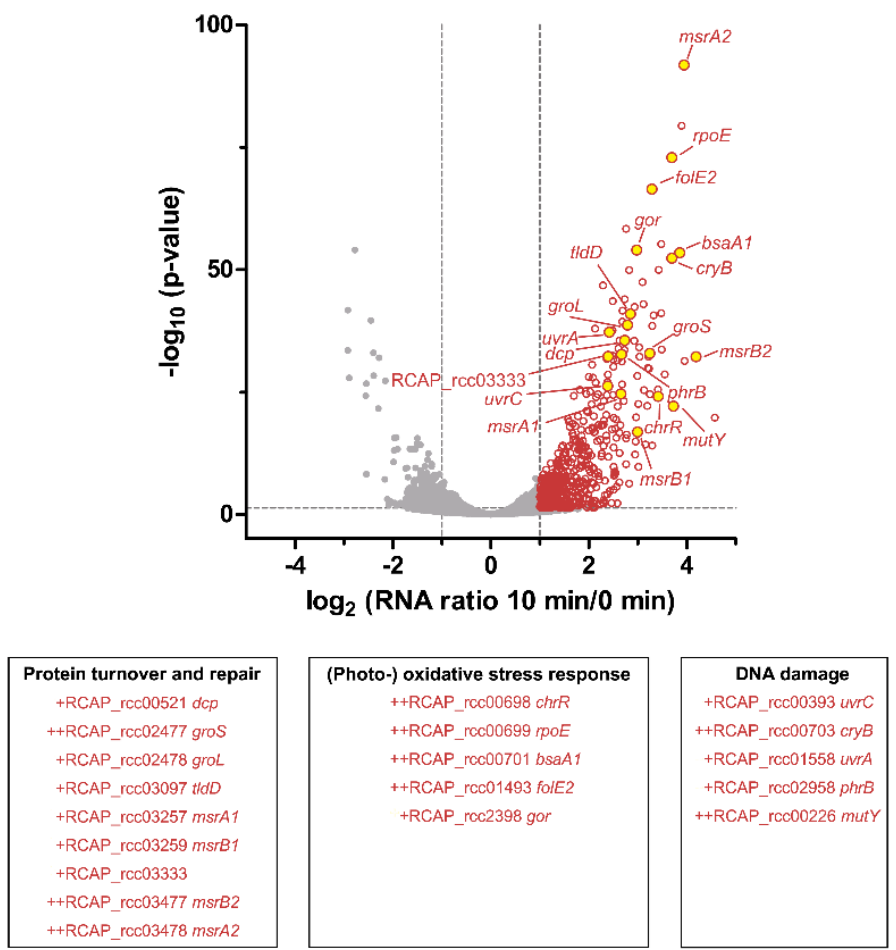

\begin{tabular}{|c|c|c|c|}
\hline \multicolumn{4}{|c|}{ Oxidation-reduction process } \\
\hline +RCAP_rcc00145 & ++RCAP_rcc01551 bcp & +RCAP_rcc02232 & ++RCAP_rcc03258 \\
\hline +RCAP_rcc00161 ghtB & +RCAP_rcc01593 cysH & +RCAP_rcc02287 yieF & +RCAP_rcc03331 ubif \\
\hline +RCAP_rcc00163gttD & ++RCAP_rcc01594 cys $t$ & ++RCAP_rcc02418 & ++RCAP_rcc03350 \\
\hline +RCAP_rcc00579 cbbL & ++RCAP_rcc01596 cobA1 & +RCAP_rcc03084 cydB & +RCAP_rcc03351 \\
\hline +RCAP_rcc01231 ubiH & ++RCAP_rcc01829 cbbM & +RCAP_rc $03085 \mathrm{cydA}$ & +RCAP_rc 03413 \\
\hline +RCAP_rcc01368 & ++RCAP_rcc01831 gap1 & +RCAP_rcc03256 & +RCAP_rcc03447 serA \\
\hline
\end{tabular}

Figure 7. Transcriptome analysis of $R$. capsulatus reveals functional groups with importance to photooxidative stress. Changes in transcript abundance after $10 \mathrm{~min}$ of photooxidative stress were determined by RNA-seq of biological triplicates. The volcano plot depicts $\log _{2}$ fold changes (10 min versus $0 \mathrm{~min}$ ) of all quantified transcripts and the corresponding $p$-values (as negative $\left.\log _{10}\right)$. The horizontal dashed line indicates the cutoff for statistical significance $(p<0.05)$, and the vertical dashed lines indicate $\log _{2}$ fold changes $\leq-1$ and $\geq 1$. Significantly increased transcripts with a $\log _{2}$ fold change $\geq 1$ are indicated as red open circles. Transcripts encoding proteins with known stress-related functions are highlighted in yellow. Boxes below the volcano plot depict functional groups as determined by GO term enrichment analysis of the 100 transcripts with the strongest increase. $\log _{2}$ fold changes of $\geq 2$ or $\geq 3$ are indicated with + and ++ , respectively.

\subsection{Similar Proteins Fulfill Important Functions in Response to Singlet Oxygen in R. sphaeroides and} R. capsulatus

It is known that changes on the RNA level are not necessarily reflected by changes in protein abundance. We therefore complemented our dataset by proteomic analysis of samples collected before (T0) and $90 \mathrm{~min}$ after the onset of ${ }^{1} \mathrm{O}_{2}$ stress (T90). Correlation between the transcriptome (T10) and proteome (T90) was fairly low (Pearson's $r$-value $=0.49$ ). Proteins were analyzed by LC-MS/MS and applied to a label-free quantification (LFQ) approach [68]. Pearson's $r$-values of $\geq 0.975$ for interreplicate comparisons demonstrated high reproducibility of the LFQ approach (Figure S7). Principal component analysis (PCA) further revealed a clear separation between T0 and T90 samples along the first dimension (Figure S6B). LFQ intensities, reflecting protein abundance, were subsequently used to calculate fold changes between conditions. In total, 1507 proteins were quantified, revealing 46 increased and 35 decreased proteins upon ${ }^{1} \mathrm{O}_{2}$ stress ( $\log _{2}$ fold change $\geq 1$ or $\leq-1$ and $p$-value $\left.<0.05\right)$. Increased proteins were subjected to GO term enrichment analysis using BiNGO in Cytoscape [58,59], 
and compared to proteome data from $R$. sphaeroides [28]. Seven homologous proteins were identified as increased in both organisms (Figure 8), including the three methionine sulfoxide reductases MsrA, MsrB1, and MsrB2, GTP cyclohydrolase FolE2, ATP-dependent protease ClpA, a putative protease (RCAP_rcc03333/RSP_1490), and an uncharacterized protein (RCAP_rcc00543/RSP_1760). All other proteins were only found to be increased in one of the two organisms (39 proteins in $R$. capsulatus and 43 proteins in $R$. sphaeroides), and only one functional group was clearly enriched in both organisms by means of GO terms, i.e., proteins with a function in oxidation-reduction processes. However, we identified several proteins with stress-related functions and grouped them accordingly (Figure 8). a prominent group relates to protein turnover and repair, including the aforementioned methionine sulfoxide reductases and several proteases, that are either increased in both organisms (ClpA and RCAP_rcc03333/RSP_1490) or only in one of the organisms (Lon, HslV, and ClpB in $R$. capsulatus; PqqL, MoxR, and ClpS in R. sphaeroides). Other proteins are directly related to the (photo-) oxidative stress response, like glutathione-disulfide reductase Gor and glutathione peroxidase BsaA1 in R. capsulatus, and a thioredoxin (RSP_0725), a peroxiredoxin (RSP_2973), and several RpoE regulon members in R. sphaeroides (Figure 8). a last group includes proteins involved in DNA damage repair, like components of the UvrABC complex and photolyase PhrB in $R$. capsulatus. Regarding other noteworthy increases, the protein $\mathrm{CbiX}$ caught our interest. As the terminal enzyme of the siroheme biosynthesis [69], CbiX does not belong to any of the described groups; however, its increase was one of the strongest. As R. sphaeroides lacked a comparable increase of the CbiX-homolog, this could hint at a core difference in the photooxidative stress responses.

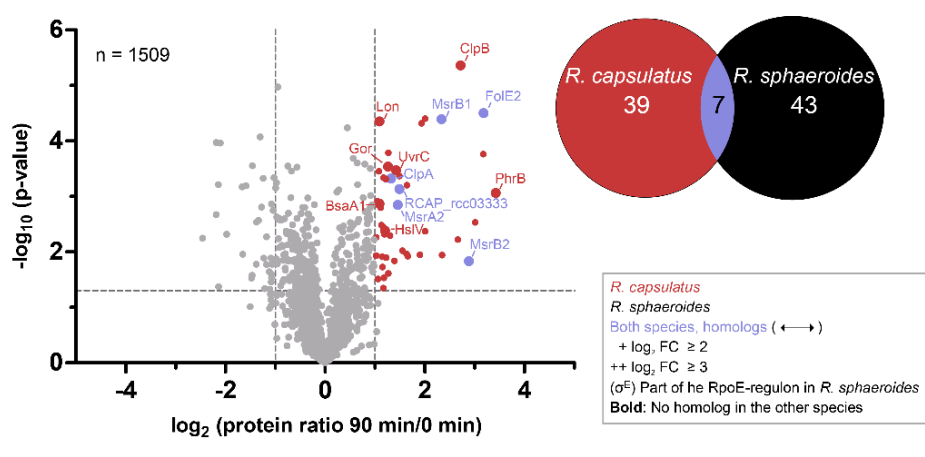

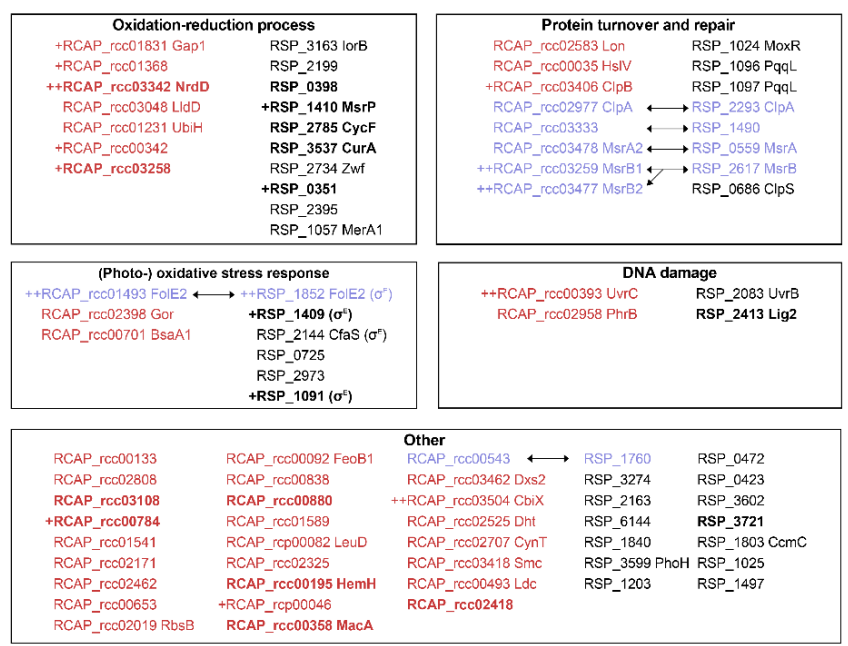

Figure 8. Functional characterization of proteins with increased abundance upon photooxidative stress. Changes in protein abundance after 90 min of photooxidative stress in $R$. capsulatus were determined by a label-free approach using LC-MS/MS of biological triplicates. 
The volcano plot depicts $\log _{2}$ fold changes (90 min versus $0 \mathrm{~min}$ ) of all quantified proteins and the corresponding $p$-values (as negative $\log _{10}$ ). The horizontal dashed line indicates the cutoff for statistical significance $(p<0.05)$, and the vertical dashed lines indicate $\log _{2}$ fold changes $\leq-1$ and $\geq$ 1. Significantly increased proteins with a $\log _{2}$ fold change $\geq 1$ are highlighted. Proteome data were compared to R. sphaeroides [28] and increased proteins illustrated in an Euler diagram. Boxes below the volcano plot depict functional groups as determined by GO term enrichment analysis. $\log _{2}$ fold changes of $\geq 2$ or $\geq 3$ are indicated with + and ++ , respectively. Colors indicate whether proteins were found only in R. capsulatus (red), only in R. sphaeroides (black), or in both species (blue). See legend for details.

\section{Discussion}

A photosynthetic lifestyle allows organisms to use light as an energy source for growth and proliferation. However, this benefit comes at a price, that is, the risk of ${ }^{1} \mathrm{O}_{2}$ generation by energy transfer from (bacterio-) chlorophyll to molecular oxygen $\left({ }^{3} \mathrm{O}_{2}\right)$ within photosynthetic complexes. It is suspected that purple bacteria from the genus Rhodobacter address this problem by avoiding strong pigmentation under high light and/or high oxygen conditions, a response that is mainly regulated by light- and oxygen-sensing proteins [2,3]. Despite regulation of pigmentation in response to oxygen tension and light, Rhodobacter species cannot completely avoid ${ }^{1} \mathrm{O}_{2}$ stress in their natural aquatic environments. They have therefore evolved strategies to counteract ${ }^{1} \mathrm{O}_{2}$ and to deal with the resulting damages $[1,65]$. $R$. sphaeroides is a well-studied model organism with regard to the photooxidative stress response [70], and was compared here to R. capsulatus using transcriptomics and proteomics. Intriguingly, the two Rhodobacter species elicit very similar responses in the light of functional categories. Many proteins with an increased abundance upon ${ }^{1} \mathrm{O}_{2}$ exposure are involved in oxidation-reduction processes and DNA damage repair (Figure 8). Furthermore, several methionine sulfoxide reductases (MsrA and MsrB orthologs) and a variety of proteases were increased, which was also confirmed on the transcript level (Figure 7). Since proteins are the main targets of ${ }^{1} \mathrm{O}_{2}$ [15], we conclude that the repair of proteins and the removal of damaged proteins is essential to survive this particular stress, and that efficient protein maintenance likely represents a key feature of the response to ${ }^{1} \mathrm{O}_{2}$ in many organisms. In R. sphaeroides, the ${ }^{1} \mathrm{O}_{2}$ stress response is mainly controlled by the alternative sigma factors RpoE and $\mathrm{RpoH}_{\text {II }}[10,18-21]$; we have reason to believe that this also holds true for $R$. capsulatus. Firstly, both rpoE and $r p o H_{I I}$ have elevated transcript levels upon ${ }^{1} \mathrm{O}_{2}$ exposure (Table 1), and secondly, an $r p o H_{I I}$ deletion strain is more sensitive to ${ }^{1} \mathrm{O}_{2}$ than the R. capsulatus wild type (Figure 6). Hence, the basic regulatory principles of the photooxidative stress response might be very similar in both Rhodobacter species.

Despite the aforementioned similarities, there are remarkable differences between $R$. sphaeroides and $R$. capsulatus. Even though both species fall into the same clade within a phylogenetic tree based on a core genome of 580 orthologous proteins [71], synteny analysis revealed that the genetic organization of orthologous genes on the chromosome is considerably different, with the exception of, e.g., the photosynthetic gene cluster (Figure S8). This pronounced genomic rearrangement is not observed between different $R$. sphaeroides strains (e.g., strains 2.4.1, KD131, and WS8N), but between different genera within the Rhodobacteraceae (e.g., between Rhodobacter and Roseobacter). Hence, our analyses suggest that $R$. capsulatus and $R$. sphaeroides are, from a genomic point of view, more distantly related than expected from their common lifestyle and the arrangement of the photosynthetic gene cluster [71]. Another remarkable finding concerns the genetic context of the rpoE-chrR locus in R. capsulatus, which is in close proximity to the photosynthetic gene cluster (Figure 4). This genetic arrangement was not found in other Rhodobacteraceae species, and can therefore be considered as unique. It is worth noting that RpoE from $R$. capsulatus shares higher identity with the extra-cytoplasmic function sigma factor SigK from Mycobacterium tuberculosis (34\%), compared to only $24 \%$ identity with $R$. sphaeroides RpoE. The same is true for $R$. capsulatus ChrR, which shares $25 \%$ identity with M. tuberculosis SigK antisigma factor RskA, but only 13\% with R. sphaeroides ChrR. Phylogenetic trees further support the special position of the R. capsulatus RpoE and ChrR proteins within the Rhodobacteraceae family (data not shown). These findings raise the question of whether the rpoE-chrR locus in $R$. capsulatus and R. sphaeroides 
originated from a common ancestor and was then intensely remodeled in $R$. capsulatus, or whether $R$. capsulatus has received a sigK-rskA-like locus from another bacterial lineage (e.g., Gram-positives like M. tuberculosis) via horizontal gene transfer.

$R$. capsulatus not only displays a unique colocalization of the photosynthetic gene cluster near the rpoE-chrR locus; it also differs to $R$. sphaeroides on the physiological level with regard to its pigmentation. a higher pigmentation of $R$. capsulatus under high oxygen conditions obviously allows much faster adaptation to occur to phototrophic conditions compared to R. sphaeroides (Figure 1B). Despite this higher pigmentation, $R$. capsulatus has no disadvantage when exposed to sudden photooxidative stress (Figure 1C). Low expression of BChl $a$ and carotenoid biosynthesis genes under aerobic conditions is reflected by low BChl $a$ and carotenoid levels in both R. capsulatus and R. sphaeroides (Figure 2A). Upon photooxidative stress, Bchl $a$ and carotenoid levels decreased in $R$. sphaeroides. By contrast, in $R$. capsulatus, only BChl a levels declined, while carotenoid levels remained fairly constant (Figure 2B), resulting in an increasing Crt:BChl $a$ ratio in the course of ${ }^{1} \mathrm{O}_{2}$ exposure (Figure 2D). These differences in $\mathrm{Crt}: \mathrm{BChl} a$ ratio may be the reason for lower ${ }^{1} \mathrm{O}_{2}$ levels in $R$. capsulatus under photooxodative stress considering the ${ }^{1} \mathrm{O}_{2}$ quenching ability of carotenoids (Figure $3 \mathrm{~A}$ ). Increased carotenoid biosynthesis under conditions of photooxidative stress is a strategy that is used by some microorganisms, including the deltaproteobacterium Myxococcus xanthus and the yeast Phaffia rhodozyma, in order to avoid extensive cellular damages by direct quenching [72,73]. Accumulation of carotenoids upon ${ }^{1} \mathrm{O}_{2}$ exposure was, however, not observed in $R$. sphaeroides [27], and omics data even revealed declining transcript and protein levels of genes from the photosynthetic gene cluster, including genes for carotenoid biosynthesis [28]. Interestingly, RNA-seq revealed that three genes within the photosynthetic gene cluster had increased transcript levels in $R$. capsulatus, which applies to $c r t I$ ( $\log _{2}$ fold change of $\sim 2.3$ ), $c r t B$ ( $\log _{2}$ fold change of $\sim 2.0$ ), and tspO ( $\log _{2}$ fold change of $\sim 1.3$ ). Induction of crtI was validated by qRT-PCR (Figure 5). The three genes form an operon between the carotenoid biosynthesis genes $c r t A$ and $c r t C$. TspO is an outer membrane protein, which controls efflux of porphyrin intermediates, and thereby negatively modulates expression of photosynthesis genes, likely through AppA [74]. The increased expression of tspO might enhance porphyrin efflux under photooxidative stress conditions, limiting both expression of photosynthesis genes and accumulation of potential porphyrin-derived photosensitizers, which may support adaptation to this particular stress. CrtB is a phytoene synthase and CrtI is a phytoene desaturase, which catalyze the reaction of precursors to phytoene $(\mathrm{CrtB})$ and from phytoene to zeta-carotene and neurosporene (CrtI). The carotenoids spheroidene (SE) and spheroidenone (SO) are then synthesized in subsequent steps from neurosporene. Even though a switch from SE to SO (catalyzed by CrtA) might be an important adaption to photooxidative stress, we could not detect a strong increase for $c r t A$ mRNA in the RNA-seq data. It is conceivable that enhanced CrtB and CrtI levels are needed to provide sufficient amounts of neurosporene as a precursor for SE and SO biosynthesis to maintain carotenoid levels in R. capsulatus (Figure 2B). By contrast, in $R$. sphaeroides crtI and crtB transcript levels do not increase upon photooxidative stress (Figure 5) [28], which even coincides with a decrease in carotenoid levels (Figure 2B). Obviously, both Rhodobacter species use different strategies to adapt to high light regimes. Since $R$. capsulatus initially grows better than $R$. sphaeroides both after a shift to phototrophic conditions (Figure 1B) and upon photooxidative stress (Figure 1C), elevated carotenoid levels are expected to be advantageous to photosynthetic bacteria in rapidly changing environments.

Besides the protective function of carotenoids, cbiX might also play a more crucial role in defending against photooxidative stress in $R$. capsulatus than in $R$. sphaeroides. Our omics data show that cbiX is strongly increased on both transcript and protein level in $R$. capsulatus ( $\log _{2}$ fold change of $\sim 3$ ). The RSP_1566 protein of $R$. sphaeroides shows $47 \%$ identity to CbiX, but neither protein nor transcript levels change significantly in response to ${ }^{1} \mathrm{O}_{2}$ [28], and cbiX transcripts were not even detected by qRT-PCR (Figure 5). The cbiX gene is annotated as a cobaltochelatase which incorporates cobalt into sirohydrochlorin to form cosirohydrochlorin, an early precursor of vitamin $\mathrm{B}_{12}$ [75]. $\mathrm{B}_{12}$ has special functions in the formation of the photosynthetic apparatus in Rhodobacter, i.e., it is required for the 
conversion of protoporphyrin IX to Mg-protoporphyrin monomethyl ester [76]. Furthermore, it is needed by the antirepressor AerR to efficiently bind to repressor CrtJ, thereby inducing bch gene expression in $R$. capsulatus $[77,78]$. Theoretically, increased CbiX levels favor $\mathrm{B}_{12}$ biosynthesis and, consequently, derepression of $b c h$ genes via AerR. However, increased bch expression would then increase photooxidative stress, but this was not observed. a structural homology search for R. capsulatus CbiX using Phyre ${ }^{2}$ suggests that it might rather act as a ferrochelatase involved in the biosynthesis of siroheme. This assumption is supported by a study by Bali and colleagues [69], showing that CbiX functionally replaces characteristic siroheme biosynthesis enzymes, which are missing in alphaproteobacteria, including $R$. sphaeroides. As siroheme is a cofactor of nitrite and sulfite reductases, an increased siroheme production might also explain the high accumulation of the mRNA for sulfite reductase CysI ( $\log _{2}$ fold change of $\sim 3.2$ ). Increased sulfur assimilation might help to counteract the ${ }^{1} \mathrm{O}_{2}$-caused depletion of glutathione and abundant damages on sulfur-containing amino acids. More importantly, however, the insertion of $\mathrm{Fe}^{2+}$ into sirohydrochlorin reduces the concentration of free iron, which would otherwise be available for both the Fenton reaction and the formation of the photosensitizer protoporphyrin IX. Hence, additional stress is prevented by changing the flux through tetrapyrrole pathways [79-81]. As a conclusion, the induction of both the $c r t I B-t s p O$ operon and cbiX might represent a successful strategy to respond to photooxidative stress, which was specifically invented in $R$. capsulatus to support adaptation. The question of whether other phototrophs have evolved similar strategies will be an exciting subject for future studies.

Supplementary Materials: The following are available online at http://www.mdpi.com/2076-2607/8/2/283/s1, Figure S1: Analysis of Rhodobacter transposon mutants (R.c. Tn5 and R.s. Tn5) lacking important carotenoids, Figure S2: Growth of $R$. capsulatus and $R$. sphaeroides with and without methylene blue in the dark or under high light conditions, Figure S3: Pigmentation of R. capsulatus and R. sphaeroides under microaerobic conditions, Figure S4: SOSG fluorescence in cell-free reactions, Figure S5: Correlation analysis of RNA-seq replicates, Figure S6: PCA of RNA-seq and LC-MS/MS replicate samples, Figure S7: Correlation analysis of LC-MS/MS replicates, Figure S8: Synteny plot comparing Rhodobacter genomes, Table S1: Strains used in this study, Table S2: Transcriptome data for Rhodobacter upon photooxidative stress, Table S3: Primers used for qRT-PCR in this study, Table S4: LC-MS/MS data for R. capsulatus upon photooxidative stress.

Author Contributions: Conceptualization, G.K.; methodology, M.K.L., A.M.N., A.K., M.B., B.A.B. and G.K.; software, M.B.; validation, M.K.L.; formal analysis, M.K.L., A.K., M.B. and B.A.B.; investigation, M.K.L., A.M.N., M.V., A.K.; data curation, M.K.L., A.K. and M.B.; writing-original draft preparation, M.K.L., B.A.B. and G.K.; writing-review and editing, M.K.L., B.A.B. and G.K.; visualization, M.K.L. and B.A.B.; supervision, B.A.B. and G.K.; project administration, G.K. All authors have read and agreed to the published version of the manuscript.

Funding: This research received no external funding.

Acknowledgments: We thank Petra Dersch (University of Münster, Germany) for generous support with RNA-seq and corrections on the manuscript, and Andrew Lang (Memorial University of Newfoundland, Canada) for providing strains.

Conflicts of Interest: The authors declare no conflict of interest.

\section{References}

1. Glaeser, J.; Nuss, A.M.; Berghoff, B.A.; Klug, G. Singlet oxygen stress in microorganisms. In Advances in Microbial Physiology; Poole, R.K., Ed.; Elsevier Ltd. Academic Press: Amsterdam, The Netherlands, 2011; Volume 58, pp. 141-173.

2. Braatsch, S.; Gomelsky, M.; Kuphal, S.; Klug, G. a single flavoprotein, AppA, integrates both redox and light signals in Rhodobacter sphaeroides. Mol. Microbiol. 2002, 45, 827-836. [CrossRef] [PubMed]

3. Han, Y.; Meyer, M.H.F.; Keusgen, M.; Klug, G. a haem cofactor is required for redox and light signalling by the AppA protein of Rhodobacter sphaeroides. Mol. Microbiol. 2007, 64, 1090-1104. [CrossRef] [PubMed]

4. Mank, N.N.; Berghoff, B.A.; Hermanns, Y.N.; Klug, G. Regulation of bacterial photosynthesis genes by the small noncoding RNA PcrZ. Proc. Natl. Acad. Sci. USA 2012, 109, 16306-16311. [CrossRef] [PubMed]

5. Eisenhardt, K.M.H.; Reuscher, C.M.; Klug, G. PcrX, an sRNA derived from the 3'-UTR of the Rhodobacter sphaeroides puf operon modulates expression of puf genes encoding proteins of the bacterial photosynthetic apparatus. Mol. Microbiol. 2018, 110, 325-334. [CrossRef] 
6. Ryter, S.W.; Tyrrell, R.M. Singlet molecular oxygen $\left({ }^{1} \mathrm{O}_{2}\right)$ : a possible effector of eukaryotic gene expression. Free Radic. Biol. Med. 1998, 24, 1520-1534. [CrossRef]

7. Davies, M.J. Singlet oxygen-mediated damage to proteins and its consequences. Biochem. Biophys. Res. Commun. 2003, 305, 761-770. [CrossRef]

8. Frimer, A.A. The reaction of singlet oxygen with olefins: The question of mechanism. Chem. Rev. 1979, 79, 359-387. [CrossRef]

9. Cavalcante, A.K.D.; Martinez, G.R.; Di Mascio, P.; Menck, C.F.M.; Agnez-Lima, L.F. Cytotoxicity and mutagenesis induced by singlet oxygen in wild type and DNA repair deficient Escherichia coli strains. DNA Repair 2002, 1, 1051-1056. [CrossRef]

10. Anthony, J.R.; Warczak, K.L.; Donohue, T.J. a transcriptional response to singlet oxygen, a toxic byproduct of photosynthesis. Proc. Natl. Acad. Sci. USA 2005, 102, 6502-6507. [CrossRef]

11. Devasagayam, T.P.A.; Steenken, S.; Obendorf, M.S.W.; Schulz, W.A.; Sies, H. Formation of 8-hydroxy (deoxy) guanosine and generation of strand breaks at guanine residues in DNA by singlet oxygen. Biochemistry 1991, 30, 6283-6289. [CrossRef]

12. Floyd, R.A.; Schneider, J.E., Jr.; Dittmer, D.P. Methylene blue photoinactivation of RNA viruses. Antiviral Res. 2004, 61, 141-151. [CrossRef]

13. Joshi, S.G.; Cooper, M.; Yost, A.; Paff, M.; Ercan, U.K.; Fridman, G.; Friedman, G.; Fridman, A.; Brooks, A.D. Non-thermal dielectric-barrier discharge (DBD) plasma-induced inactivation involves oxidative-DNA damage and membrane lipid peroxidation in Escherichia coli. Antimicrob. Agents Chemother. 2011, 55, 1053-1062. [CrossRef] [PubMed]

14. Riske, K.A.; Sudbrack, T.P.; Archilha, N.L.; Uchoa, A.F.; Schroder, A.P.; Marques, C.M.; Baptista, M.S.; Itri, R. Giant vesicles under oxidative stress induced by a membrane-anchored photosensitizer. Biophys. J. 2009, 97, 1362-1370. [CrossRef] [PubMed]

15. Davies, M.J. Reactive species formed on proteins exposed to singlet oxygen. Photochem. Photobiol. Sci. 2004, 3, 17-25. [CrossRef]

16. Wilkinson, F.; Helman, W.P.; Ross, A.B. Rate constants for the decay and reactions of the lowest electronically excited singlet state of molecular oxygen in solution. An expanded and revised compilation. J. Phys. Chem. Ref. Data 1995, 24, 663-677. [CrossRef]

17. Pattison, D.I.; Rahmanto, A.S.; Davies, M.J. Photo-oxidation of proteins. Photochem. Photobiol. Sci. 2012, 11, 38-53. [CrossRef]

18. Glaeser, J.; Zobawa, M.; Lottspeich, F.; Klug, G. Protein synthesis patterns reveal a complex regulatory response to singlet oxygen in Rhodobacter. J. Proteome Res. 2007, 6, 2460-2471. [CrossRef]

19. Nuss, A.M.; Glaeser, J.; Klug, G. $\mathrm{RpoH}_{\mathrm{II}}$ activates oxidative-stress defense systems and is controlled by RpoE in the singlet oxygen-dependent response in Rhodobacter sphaeroides. J. Bacteriol. 2009, 191, 220-230. [CrossRef]

20. Nuss, A.M.; Glaeser, J.; Berghoff, B.A.; Klug, G. Overlapping alternative sigma factor regulons in the response to singlet oxygen in Rhodobacter sphaeroides. J. Bacteriol. 2010, 192, 2613-2623. [CrossRef]

21. Dufour, Y.S.; Imam, S.; Koo, B.-M.; Green, H.A.; Donohue, T.J. Convergence of the transcriptional responses to heat shock and singlet oxygen stresses. PLoS Genet. 2012, 8, e1002929. [CrossRef]

22. Nuss, A.M.; Adnan, F.; Weber, L.; Berghoff, B.A.; Glaeser, J.; Klug, G. DegS and RseP homologous proteases are involved in singlet oxygen dependent activation of RpoE in Rhodobacter sphaeroides. PLoS ONE 2013, 8, e79520. [CrossRef] [PubMed]

23. Nam, T.-W.; Ziegelhoffer, E.C.; Lemke, R.A.S.; Donohue, T.J. Proteins needed to activate a transcriptional response to the reactive oxygen species singlet oxygen. MBio 2013, 4, e00541-12. [CrossRef] [PubMed]

24. Hendrischk, A.-K.; Braatsch, S.; Glaeser, J.; Klug, G. The phrA gene of Rhodobacter sphaeroides encodes

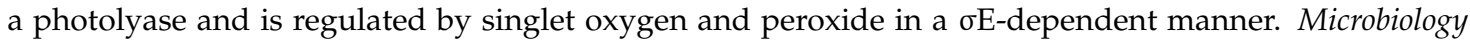
2007, 153, 1842-1851. [CrossRef] [PubMed]

25. Dufour, Y.S.; Landick, R.; Donohue, T.J. Organization and evolution of the biological response to singlet oxygen stress. J. Mol. Biol. 2008, 383, 713-730. [CrossRef]

26. Lemke, R.A.S.; Peterson, A.C.; Zieglhoffer, E.C.; Westphall, M.S.; Tjellström, H.; Coon, J.J.; Donohue, T.J. Synthesis and scavenging role of furan fatty acids. Proc. Natl. Acad. Sci. USA 2014, 111, E3451. [CrossRef]

27. Glaeser, J.; Klug, G. Photo-oxidative stress in Rhodobacter sphaeroides: Protective role of carotenoids and expression of selected genes. Microbiology 2005, 151, 1927-1938. [CrossRef] 
28. Berghoff, B.A.; Konzer, A.; Mank, N.N.; Looso, M.; Rische, T.; Förstner, K.U.; Krüger, M.; Klug, G. Integrative "Omics"-approach discovers dynamic and regulatory features of bacterial stress responses. PLoS Genet. 2013, 9, e1003576. [CrossRef]

29. Schmidt, K. Biosynthesis of carotenoids. In The Photosynthetic Bacteria; Clayton, R.K., Sistrom, W.R., Eds.; Prenum Press: New York, NY, USA, 1978; pp. 729-750.

30. Scolnik, P.A.; Walker, M.A.; Marrs, B.L. Biosynthesis of carotenoids derived from neurosporene in Rhodopseudomonas capsulata. J. Biol. Chem. 1980, 255, 2427-2432.

31. Zhu, Y.S.; Cook, D.N.; Leach, F.; Armstrong, G.A.; Alberti, M.; Hearst, J.E. Oxygen-regulated mRNAs for light-harvesting and reaction center complexes and for bacteriochlorophyll and carotenoid biosynthesis in Rhodobacter capsulatus during the shift from anaerobic to aerobic growth. J. Bacteriol. 1986, 168, 1180-1188. [CrossRef]

32. Yeliseev, A.A.; Eraso, J.M.; Kaplan, S. Differential carotenoid composition of the B875 and B800-850 photosynthetic antenna complexes in Rhodobacter sphaeroides 2.4.1: Involvement of spheroidene and spheroidenone in adaptation to changes in light intensity and oxygen availability. J. Bacteriol. 1996, 178, 5877-5883. [CrossRef]

33. Li, Z.; Kong, L.; Hui, B.; Shang, X.; Gao, L.; Luan, N.; Zhuang, X.; Wang, D.; Bai, Z. Identification and antioxidant activity of carotenoids from superfine powder of Rhodobacter sphaeroides. Emirates J. Food Agric. 2017, 29, 833-845. [CrossRef]

34. Šlouf, V.; Chábera, P.; Olsen, J.D.; Martin, E.C.; Qian, P.; Hunter, C.N.; Polívka, T. Photoprotection in a purple phototrophic bacterium mediated by oxygen-dependent alteration of carotenoid excited-state properties. Proc. Natl. Acad. Sci. USA 2012, 109, 8570-8575. [CrossRef]

35. Berghoff, B.A.; Glaeser, J.; Sharma, C.M.; Vogel, J.; Klug, G. Photooxidative stress-induced and abundant small RNAs in Rhodobacter sphaeroides. Mol. Microbiol. 2009, 74, 1497-1512. [CrossRef]

36. Berghoff, B.A.; Glaeser, J.; Sharma Cynthia, M.; Zobawa, M.; Lottspeich, F.; Vogel, J.; Klug, G. Contribution of Hfq to photooxidative stress resistance and global regulation in Rhodobacter sphaeroides. Mol. Microbiol. 2011, 80, 1479-1495. [CrossRef]

37. Billenkamp, F.; Peng, T.; Berghoff, B.A.; Klug, G. a cluster of four homologous small RNAs modulates C-1 metabolism and the pyruvate dehydrogenase complex in Rhodobacter sphaeroides under various stress conditions. J. Bacteriol. 2015, 197, 1839-1852. [CrossRef]

38. Müller, K.M.H.; Berghoff, B.A.; Eisenhardt, B.D.; Remes, B.; Klug, G. Characteristics of Pos19—A small coding RNA in the oxidative stress response of Rhodobacter sphaeroides. PLoS ONE 2016, 11, e0163425. [CrossRef]

39. Adnan, F.; Weber, L.; Klug, G. The sRNA SorY confers resistance during photooxidative stress by affecting a metabolite transporter in Rhodobacter sphaeroides. RNA Biol. 2015, 12, 569-577. [CrossRef]

40. Peng, T.; Berghoff, B.A.; Oh, J.-I.; Weber, L.; Schirmer, J.; Schwarz, J.; Glaeser, J.; Klug, G. Regulation of a polyamine transporter by the conserved 3' UTR-derived sRNA SorX confers resistance to singlet oxygen and organic hydroperoxides in Rhodobacter' sphaeroides. RNA Biol. 2016, 13, 988-999. [CrossRef]

41. Klug, G.; Adams, C.W.; Belasco, J.; Doerge, B.; Cohen, S.N. Biological consequences of segmental alterations in mRNA stability: Effects of deletion of the intercistronic hairpin loop region of the Rhodobacter capsulatus puf operon. EMBO J. 1987, 6, 3515-3520. [CrossRef]

42. Gregor, J.; Klug, G. Regulation of bacterial photosynthesis genes by oxygen and light. FEMS Microbiol. Lett. 1999, 179, 1-9. [CrossRef]

43. Remes, B.; Berghoff, B.A.; Foerstner, K.U.; Klug, G. Role of oxygen and the OxyR protein in the response to iron limitation in Rhodobacter sphaeroides. BMC Genom. 2014, 15, 794. [CrossRef]

44. Shiozawa, J.A.; Welte, W.; Hodapp, N.; Drews, G. Studies on the size and composition of the isolated light-harvesting B800-850 pigment-protein complex of Rhodopseudomonas capsulata. Arch. Biochem. Biophys. 1982, 213, 473-485. [CrossRef]

45. Clayton, R.K. The bacterial photosynthetic reaction center. In Proceedings of the Brookhaven Symposia in Biology, New York, NY, USA, 6-9 June 1966; Volume 19, pp. 62-70.

46. Janzon, L.; Löfdahl, S.; Arvidson, S. Evidence for a coordinate transcriptional control of alpha-toxin and protein a synthesis in Staphylococcus aureus. FEMS Microbiol. Lett. 1986, 33, 193-198. [CrossRef]

47. Nuss, A.M.; Heroven, A.K.; Waldmann, B.; Reinkensmeier, J.; Jarek, M.; Beckstette, M.; Dersch, P. Transcriptomic profiling of Yersinia pseudotuberculosis reveals reprogramming of the Crp regulon by temperature and uncovers Crp as a master regulator of small RNAs. PLoS Genet. 2015, 11, e1005087. [CrossRef] 
48. Aronesty, E. ea-Utils: Command-Line Tools for Processing Biological Sequencing Data. 2011. Available online: https://github.com/ExpressionAnalysis/ea-utils (accessed on 19 February 2020).

49. Langmead, B.; Salzberg, S.L. Fast gapped-read alignment with Bowtie 2. Nat. Methods 2012, 9, 357-359. [CrossRef]

50. Li, H.; Handsaker, B.; Wysoker, A.; Fennell, T.; Ruan, J.; Homer, N.; Marth, G.; Abecasis, G.; Durbin, R. The sequence alignment/map format and SAMtools. Bioinformatics 2009, 25, 2078-2079. [CrossRef]

51. Love, M.I.; Huber, W.; Anders, S. Moderated estimation of fold change and dispersion for RNA-seq data with DESeq2. Genome Biol. 2014, 15, 550. [CrossRef]

52. Pfaffl, M.W. a new mathematical model for relative quantification in real-time RT-PCR. Nucleic. Acids Res. 2001, 29, e45. [CrossRef]

53. Bathke, J.; Konzer, A.; Remes, B.; McIntosh, M.; Klug, G. Comparative analyses of the variation of the transcriptome and proteome of Rhodobacter sphaeroides throughout growth. BMC Genom. 2019, 20, 358. [CrossRef]

54. Cox, J.; Mann, M. MaxQuant enables high peptide identification rates, individualized ppb-range mass accuracies and proteome-wide protein quantification. Nat. Biotechnol. 2008, 26, 1367-1372. [CrossRef]

55. Chen, I.-M.A.; Chu, K.; Palaniappan, K.; Pillay, M.; Ratner, A.; Huang, J.; Huntemann, M.; Varghese, N.; White, J.R.; Seshadri, R.; et al. IMG/M v. 5.0: An integrated data management and comparative analysis system for microbial genomes and microbiomes. Nucleic Acids Res. 2019, 47, D666-D677. [CrossRef]

56. Kelley, L.A.; Mezulis, S.; Yates, C.M.; Wass, M.N.; Sternberg, M.J.E. The Phyre2 web portal for protein modeling, prediction and analysis. Nat. Protoc. 2015, 10, 845-858. [CrossRef]

57. Blom, J.; Kreis, J.; Spänig, S.; Juhre, T.; Bertelli, C.; Ernst, C.; Goesmann, A. EDGAR 2.0: An enhanced software platform for comparative gene content analyses. Nucleic Acids Res. 2016, 44, W22-W28. [CrossRef]

58. Shannon, P.; Markiel, A.; Ozier, O.; Baliga, N.S.; Wang, J.T.; Ramage, D.; Amin, N.; Schwikowski, B.; Ideker, T. Cytoscape: a software environment for integrated models of biomolecular interaction networks. Genome Res. 2003, 13, 2498-2504. [CrossRef] [PubMed]

59. Maere, S.; Heymans, K.; Kuiper, M. BiNGO: a Cytoscape plugin to assess overrepresentation of gene ontology categories in biological networks. Bioinformatics 2005, 21, 3448-3449. [CrossRef] [PubMed]

60. Botstein, D.; Cherry, J.M.; Ashburner, M.; Ball, C.A.; Blake, J.A.; Butler, H.; Davis, A.P.; Dolinski, K.; Dwight, S.S.; Eppig, J.T.; et al. Gene Ontology: Tool for the unification of biology. Nat. Genet. 2000, 25, $25-29$.

61. Carbon, S.; Douglass, E.; Dunn, N.; Good, B.; Harris, N.L.; Lewis, S.E.; Mungall, C.J.; Basu, S.; Chisholm, R.L.; Dodson, R.J.; et al. The Gene Ontology Resource: 20 years and still going strong. Nucleic Acids Res. 2019, 47, D330-D338.

62. Prasad, A.; Sedlářová, M.; Pospíši, P. Singlet oxygen imaging using fluorescent probe Singlet Oxygen Sensor Green in photosynthetic organisms. Sci. Rep. 2018, 8, 13685. [CrossRef]

63. Dwyer, D.J.; Belenky, P.A.; Yang, J.H.; MacDonald, I.C.; Martell, J.D.; Takahashi, N.; Chan, C.T.Y.; Lobritz, M.A.; Braff, D.; Schwarz, E.G.; et al. Antibiotics induce redox-related physiological alterations as part of their lethality. Proc. Natl. Acad. Sci. USA 2014, 111, E2100-E2109. [CrossRef]

64. Davies, M.J. Protein oxidation and peroxidation. Biochem. J. 2016, 473, 805-825. [CrossRef]

65. Ziegelhoffer, E.C.; Donohue, T.J. Bacterial responses to photo-oxidative stress. Nat. Rev. Microbiol. 2009, 7, 856-863. [CrossRef] [PubMed]

66. Hendrischk, A.-K.; Frühwirth, S.W.; Moldt, J.; Pokorny, R.; Metz, S.; Kaiser, G.; Jäger, A.; Batschauer, A.; Klug, G. a cryptochrome-like protein is involved in the regulation of photosynthesis genes in Rhodobacter sphaeroides. Mol. Microbiol. 2009, 74, 990-1003. [CrossRef] [PubMed]

67. Berghoff, B.A.; Glaeser, J.; Nuss, A.M.; Zobawa, M.; Lottspeich, F.; Klug, G. Anoxygenic photosynthesis and photooxidative stress: a particular challenge for Roseobacter. Environ. Microbiol. 2011, 13, 775-791. [CrossRef] [PubMed]

68. Cox, J.; Hein, M.Y.; Luber, C.A.; Paron, I.; Nagaraj, N.; Mann, M. Accurate proteome-wide label-free quantification by delayed normalization and maximal peptide ratio extraction, termed MaxLFQ. Mol. Cell Proteom. 2014, 13, 2513-2526. [CrossRef]

69. Bali, S.; Rollauer, S.; Roversi, P.; Raux-Deery, E.; Lea, S.; Warren, M.J.; Ferguson, S.J. Identification and characterization of the "missing" terminal enzyme for siroheme biosynthesis in $\alpha$-proteobacteria. Mol. Microbiol. 2014, 92, 153-163. [CrossRef] 
70. Berghoff, B.A.; Klug, G. An omics view on the response to singlet oxygen. In Stress and Environmental Regulation of Gene Expression and Adaptation in Bacteria; de Bruijn, F.J., Ed.; John Wiley \& Sons, Inc.: Hoboken, NJ, USA, 2016; Volume 1, pp. 619-631.

71. Brinkmann, H.; Göker, M.; Koblížek, M.; Wagner-Döbler, I.; Petersen, J. Horizontal operon transfer, plasmids, and the evolution of photosynthesis in Rhodobacteraceae. ISME J. 2018, 12, 1984-2010. [CrossRef]

72. Schroeder, W.A.; Johnson, E.A. Carotenoids protect Phaffia rhodozyma against singlet oxygen damage. J. Ind. Microbiol. 1995, 14, 502-507. [CrossRef]

73. Galbis-Martínez, M.; Padmanabhan, S.; Murillo, F.J.; Elías-Arnanz, M. CarF mediates signaling by singlet oxygen, generated via photoexcited protoporphyrin IX, in Myxococcus xanthus light-induced carotenogenesis. J. Bacteriol. 2012, 194, 1427-1436. [CrossRef]

74. Zeng, X.; Kaplan, S. TspO as a modulator of the repressor/antirepressor (PpsR/AppA) regulatory system in Rhodobacter sphaeroides 2.4. 1. J. Bacteriol. 2001, 183, 6355-6364. [CrossRef]

75. Leech, H.K.; Raux-Deery, E.; Heathcote, P.; Warren, M.J. Production of cobalamin and sirohaem in Bacillus megaterium: An investigation into the role of the branchpoint chelatases sirohydrochlorin ferrochelatase (SirB) and sirohydrochlorin cobalt chelatase (CbiX). Biochem. Soc. Trans. 2002, 30, 610-613. [CrossRef]

76. Gough, S.P.; Petersen, B.O.; Duus, J.Ø. Anaerobic chlorophyll isocyclic ring formation in Rhodobacter capsulatus requires a cobalamin cofactor. Proc. Natl. Acad. Sci. USA 2000, 97, 6908-6913. [CrossRef] [PubMed]

77. Cheng, Z.; Li, K.; Hammad, L.A.; Karty, J.A.; Bauer, C.E. Vitamin B 12 regulates photosystem gene expression via the CrtJ antirepressor AerR in Rhodobacter capsulatus. Mol. Microbiol. 2014, 91, 649-664. [CrossRef]

78. Klug, G. Beyond catalysis: Vitamin B12 as a cofactor in gene regulation. Mol. Microbiol. 2014, 91, 635-640. [CrossRef]

79. Kim, J.-G.; Back, K.; Lee, H.Y.; Lee, H.-J.; Phung, T.-H.; Grimm, B.; Jung, S. Increased expression of Fe-chelatase leads to increased metabolic flux into heme and confers protection against photodynamically induced oxidative stress. Plant Mol. Biol. 2014, 86, 271-287. [CrossRef] [PubMed]

80. Dai, J.; Wei, H.; Tian, C.; Damron, F.H.; Zhou, J.; Qiu, D. An extracytoplasmic function sigma factor-dependent periplasmic glutathione peroxidase is involved in oxidative stress response of Shewanella oneidensis. BMC Microbiol. 2015, 15, 34. [CrossRef] [PubMed]

81. Qiu, D.; Xie, M.; Dai, J.; An, W.; Wei, H.; Tian, C.; Kempher, M.L.; Zhou, A.; He, Z.; Gu, B.; et al. Differential regulation of the two ferrochelatase paralogues in Shewanella loihica PV-4 in response to environmental stresses. Appl. Environ. Microbiol. 2016, 82, 5077-5088. [CrossRef] 